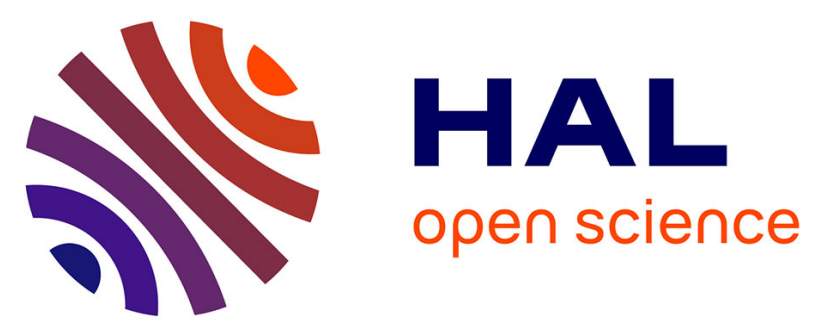

\title{
Evaluation of 2-(salicylideneimino) thiophenol and other Schiff bases as bronze corrosion inhibitors by electrochemical techniques and surface analysis
}

\author{
Cecilia Monticelli, Andrea Balbo, Jérôme Esvan, Cristina Chiavari, Carla
}

Martini, Federica Zanotto, Lorenza Marvelli, Luc Robbiola

\section{To cite this version:}

Cecilia Monticelli, Andrea Balbo, Jérôme Esvan, Cristina Chiavari, Carla Martini, et al.. Evaluation of 2-(salicylideneimino) thiophenol and other Schiff bases as bronze corrosion inhibitors by electrochemical techniques and surface analysis. Corrosion Science, 2019, 148, pp.144-158. 10.1016/j.corsci.2018.12.017 . hal-03033080

\section{HAL Id: hal-03033080 https://hal.science/hal-03033080}

Submitted on 1 Dec 2020

HAL is a multi-disciplinary open access archive for the deposit and dissemination of scientific research documents, whether they are published or not. The documents may come from teaching and research institutions in France or abroad, or from public or private research centers.
L'archive ouverte pluridisciplinaire HAL, est destinée au dépôt et à la diffusion de documents scientifiques de niveau recherche, publiés ou non, émanant des établissements d'enseignement et de recherche français ou étrangers, des laboratoires publics ou privés. 


\section{OATAO \\ Open Archive Toulouse Archive Ouverte}

\section{Open Archive Toulouse Archive Ouverte (OATAO)}

OATAO is an open access repository that collects the work of Toulouse researchers and makes it freely available over the web where possible

This is an author's version published in: http://oatao.univ-toulouse.fr/26618

Official URL: https://doi.org/10.1016/j.corsci.2018.12.017

To cite this version: Monticelli, $C$. and Balbo, A. and Esvan, Jérôme $\leftrightarrows$ and Chiavari, C. and Martini, C. and Zanotto, F. and Marvelli, L. and Robbiola, Luc $\leftrightarrows$ Evaluation of 2-(salicylideneimino) thiophenol and other Schiff bases as bronze corrosion inhibitors by electrochemical techniques and surface analysis. (2018) Corrosion Science, 148. 144-158. ISSN 0010-938X

Any correspondence concerning this service should be sent to the repository administrator: tech-oatao@listes-diff.inp-toulouse.fr 


\title{
Evaluation of 2-(salicylideneimino) thiophenol and other Schiff bases as bronze corrosion inhibitors by electrochemical techniques and surface analysis
}

\author{
C. Monticelli ${ }^{\mathrm{a}, *}$, A. Balbo ${ }^{\mathrm{a}}$, J. Esvan $^{\mathrm{b}}$, C. Chiavari ${ }^{\mathrm{c}}$, C. Martini ${ }^{\mathrm{d}}$, F. Zanotto $^{\mathrm{a}}$, L. Marvelli ${ }^{\mathrm{e}}$, \\ L. Robbiola ${ }^{\mathrm{f}}$
}

${ }^{a}$ Centro di Studi sulla Corrosione e Metallurgia "A. Daccò", Dipartimento di Ingegneria, Università di Ferrara, Via G. Saragat 4/a, 44122 Ferrara, Italy

${ }^{\mathrm{b}}$ Centre Interuniversitaire de Recherche et d'Ingénierie des Matériaux, Université de Toulouse, 4 allée Emile Monso, 31030 Toulouse, France

${ }^{\mathrm{c}}$ Dipartimento di Beni Culturali, Università di Bologna, via degli Ariani 1, 48121 Ravenna, Italy

${ }^{\mathrm{d}}$ Dipartimento di Ingegneria Industriale, Università di Bologna, viale Risorgimento 4, 40136 Bologna, Italy

${ }^{\mathrm{e}}$ Dipartimento di Scienze Chimiche e Farmaceutiche, Università di Ferrara, Via L. Borsari 46, 44121 Ferrara, Italy

${ }^{\mathrm{f}}$ TRACES lab (CNRS UMR 5608), Université de Toulouse, allées Antonio-Machado, 31058 Toulouse, France

\section{A R T I C L E I N F O}

Keywords:

Bronze

Corrosion inhibitor

Schiff bases

EIS

XPS
A B S T R A C T

In this research, different Schiff bases were synthesized and tested as bronze corrosion inhibitors in concentrated synthetic acid rain at $\mathrm{pH}$ 3.3. Some of them showed good inhibiting effects, as detected by EIS and polarization curve recording. The most efficient inhibitor (2-(salicylideneimino) thiophenol, SITP) was also tested with addition of sodium dihydrogen phosphate (P). P improved the surface film resistance against breakdown phenomena. XPS and SEM investigations showed that SITP and SITP + P significantly hinder decuprification. Moreover, SITP forms a protective layer on bronze, composed of both Cu(I)-SITP complexes and adsorbed inhibitor molecules. $\mathrm{Cu}(\mathrm{II})$ phosphates were also detected with $\mathrm{P}$ addition.

\section{Introduction}

Ancient and modern bronze artefacts are an important part of our cultural heritage and the development of effective protective treatments with no adverse effect on health and environment is still an unresolved issue. This research deals with the identification of new bronze corrosion inhibitors in concentrated synthetic acid rain and represents a first step in a more complex research activity, aiming at developing new non-hazardous protective coatings for outdoor bronze artefacts, entrapping corrosion inhibitors. In a subsequent step of this research, the most efficient substance will be encapsulated in the coatings with the aim to increase their long term protectiveness. Some preliminary results were presented in [1].

Up to now, the most efficient organic inhibitors of bronze corrosion have mainly been azoles and particularly triazoles [2-4], tetrazoles [2,5], imidazoles [6] and thiadiazoles [2,5,7,8]. The inhibition mechanism of these substances has been investigated above all on copper, as it is the main alloying element in bronze. Chemisorption was found to occur through the electron lone pairs in $\mathrm{N}$ atoms and/or through delocalized $\pi$-electrons in aromatic rings favoured by the concomitant presence of other heteroatoms with donor nature, like $\mathrm{S}$, either in the ring or in functional groups [9]. In acid solutions, azole adsorption is weak suggesting that it mainly occurs through the deprotonated molecular forms [10-12], except for molecules of very basic nature like imidazoles, which also adsorb significantly in the neutral form [13-15]. Whether azoles adsorb directly on copper metal [16-18] or on a surface cuprous oxide film is still under debate $[9,19,20]$. Some authors couple the two theories and maintain that, after an initial step of direct adsorption on the metal surface, slow copper oxidation to $\mathrm{Cu}(\mathrm{I})$ proceeds and determines the subsequent growth of a polymeric $\mathrm{Cu}(\mathrm{I})$-inhibitor film [21-23], which most likely lies [24-26] on a thin $\mathrm{Cu}_{2} \mathrm{O}$ inner layer. A $24 \AA$ thick $\mathrm{Cu}(\mathrm{I})-\mathrm{BTA}$ layer doped with $\mathrm{Cu}_{2} \mathrm{O}$ was found to grow on copper in neutral chloride solution after short immersion times [27].

In the field of bronze heritage conservation [2,4], BTA and triazole derivatives are the most commonly used inhibitors, even if toxicity concerns have been raised regarding BTA as a result of its leaching into the environment [28] and suspected carcinogenicity to humans [29].

Some substances, belonging to the class of Schiff bases and

\footnotetext{
* Corresponding author.

E-mail addresses: mtc@unife.it (C. Monticelli), andrea.balbo@unife.it (A. Balbo), jerome.esvan@ensiacet.fr (J. Esvan), cristina.chiavari@unibo.it (C. Chiavari), carla.martini@unibo.it (C. Martini), zntfrc@unife.it (F. Zanotto), lorenza.marvelli@unife.it (L. Marvelli), robbiola@univ-tlse2.fr (L. Robbiola).
} 
considered non-toxic to the environment [30], have been proven to be efficient inhibitors of copper corrosion in acidic and neutral solutions of chlorides [19,30-33]. They are claimed to produce thin protective layers on the metal surface, by forming $\mathrm{N}-\mathrm{Cu}$ coordinate bonds or $\pi$ electron interactions with the surface $\mathrm{Cu}_{2} \mathrm{O}$ film [30]. The introduction of a thiol group into the molecular structure favours the inhibitor chemisorption on pure copper from hydroalcoholic solutions [31].

In our laboratory, some Schiff bases were purposely synthesized and investigated as corrosion inhibitors of bronze during $480 \mathrm{~h}$ of immersion in concentrated synthetic acid rain. Since some phosphonates mixed with amine substances revealed a synergistic inhibition effect against steel corrosion [34], the onset of a similar synergistic inhibition effect was attempted by adding phosphate ions to the most efficient Schiff base (i.e. 2-salicylideneimine thiophenol, SITP). The composition and microstructure of the bronze substrate used during the tests were comparable to those of Renaissance bronze [5]. When in contact with a concentrated synthetic acid rain, a patina which is very similar to those actually found on ancient bronze artworks develops [35].

The mechanism of SITP corrosion inhibition, in the absence and presence of phosphate ions, wasstudied not only by electrochemical techniques, but also by scanning electron microscope associated with energy dispersive spectroscopy (SEM-EDS), Raman spectroscopy and Xray photoelectron spectroscopy (XPS). These techniques led to a better understanding of the influence of the inhibitor addition against bronze decuprification.

\section{Experimental part}

\subsection{Specimens and aggressive environment}

The specimens were cut from an as-cast bronze alloy sheet with composition (91.9 Cu, 2.4 Sn, 1.0 Pb, Zn 2.9, 0.8 Sb, wt.\%) and microstructure reproducing those of Renaissance bronze artefacts with cored dendrites of $\mathrm{Cu}$-solid solution with $\mathrm{Sn}$ - and $\mathrm{Sb}$ - local enrichment, also including $\mathrm{Pb}$ globules in the interdendritic spaces, as reported in previous papers $[5,35,36]$.

Bronze electrodes were soldered to sheathed copper wires to ensure electrical connection for electrochemical tests and then embedded in epoxy, with an exposed surface area of $1 \mathrm{~cm}^{2}$. Before immersion in the aggressive solutions, the electrode surface was prepared by grinding with emery papers up to P 1000 grade and then polished with $1 \mu \mathrm{m}$ diamond powder to a mirror finishing. Finally, they were degreased with ethyl alcohol and washed with deionized water.

The test solution consisted of a tenfold concentrated synthetic acid rain ( $\mathrm{pH}$ 3.3) indicated as ARX10 and prepared according to the recipe reported in [37]. In ARX10, the ion concentrations were: $\mathrm{SO}_{4}{ }^{2-}$ $19.0 \mathrm{mg} \mathrm{L}^{-1}$, Cl- $12.7 \mathrm{mg} \mathrm{L}^{-1}, \mathrm{NO}_{3^{-}} 46.2 \mathrm{mg} \mathrm{L}^{-1}, \mathrm{CH}_{3} \mathrm{COO}-2.3 \mathrm{mg} \mathrm{L}^{-1}$, HCOO- $0.5 \mathrm{mg} \mathrm{L}^{-1}, \mathrm{NH}_{4}^{+} 10.5 \mathrm{mg} \mathrm{L}^{-1}, \mathrm{Ca}^{2+} 3.4 \mathrm{mg} \mathrm{L}^{-1}, \mathrm{Na}^{+} 5.3 \mathrm{mg} \mathrm{L}^{-1}$. The solution temperature was $30^{\circ} \mathrm{C}$.

The Schiff bases tested as corrosion inhibitors were 2-(salicylideneimino) thiophenol (SITP), 2-salicylideneimino) aminophenol (SIAP), 2 - (3-methoxy-salicylideneimino) thiophenol (MSITP), N,N'-O-phenylen-bis(3-methoxy-salicylideneimine) (PMSI) and [2-(2-thiophenyl) imino]-1,2-diphenylethanone (TPIE), with structural formulas reported in Fig. 1. They were synthesised starting from the corresponding amines and aldehydes in the Inorganic Chemistry Laboratory of the University of Ferrara and their purity was checked by elemental analysis, Fourier Transform Infrared (FTIR) spectroscopy and Proton Nuclear Magnetic Resonance $\left({ }^{1} \mathrm{H}\right.$ NMR) technique. Given the low Schiff bases solubility, they were always tested as ARX10 solutions saturated at $30{ }^{\circ} \mathrm{C}$ and filtered. The saturation concentrations in ARX10 at $30^{\circ} \mathrm{C}$ were $0.7 \mathrm{mM}$ (in the case of SITP), $0.3 \mathrm{mM}$ (SIAP, MSITP, PMSI) and $0.4 \mathrm{mM}$ (TPIE).

The inhibiting efficiency of the most concentrated and most effective substance (SITP) was also evaluated in the presence of phosphate ions, added as sodium dihydrogen phosphate $\left(\mathrm{NaH}_{2} \mathrm{PO}_{4}\right.$, henceforward indicated by the label $\mathrm{P}$ ), at the concentration of $10^{-2} \mathrm{M}$. The addition of $\mathrm{P}$ determined a negligible increase in solution $\mathrm{pH}$ compared to that of the ARX10 solution containing or not containing the Schiff bases (from 3.3 to 3.6). Reference tests were also carried out in ARX10 in the presence of only $10^{-2} \mathrm{MP}$.

\subsection{Electrochemical tests}

Electrochemical tests were carried out in a conventional thermostated three-electrode cell using a EG\&G potentiostat/galvanostat model $273 \mathrm{~A}$, piloted by PowerSuite software. The reference and auxiliary electrodes were a saturated calomel electrode (SCE) and a Pt sheet, respectively. All the potential values quoted in the text refer to SCE. Three experiments were carried out under each experimental condition.

Electrochemical Impedance Spectroscopy (EIS) tests were performed at the open circuit potential during $480 \mathrm{~h}$ exposures to uninhibited and inhibited solutions by applying a voltage perturbation amplitude of $10 \mathrm{mV}$ (rms) in the frequency range $10^{4}-10^{-3} \mathrm{~Hz}$ with 5 points per frequency decade. The spectra were fitted by SAI ZView v.3.5c software, according to the most suitable equivalent circuit, as described in the text.

Ohmic drop-compensated polarization curves were recorded after both $1 \mathrm{~h}$ immersion and at the end of the 20 days of immersion in uninhibited or inhibited ARX10, always starting from the corrosion potential $\left(\mathrm{E}_{\mathrm{cor}}\right)$ and reaching a cathodic polarization of $-0.300 \mathrm{~V}$ vs $\mathrm{E}_{\mathrm{cor}}$, in the case of the cathodic branch, and up to a current density of about $3 \mathrm{~mA} \mathrm{~cm}^{-2}$ (or $+0.5 \mathrm{~V}_{\mathrm{SCE}}$, the first of the two limits), in the case of the anodic branch. The potential scan rate was $0.167 \mathrm{mV} \mathrm{s}^{-1}$. The Levenburg-Marquardt (LEV) method was applied (by software SAI CView v.3.5c) to properly fit the coupled anodic and cathodic polarization curves to the following equation:

$j=j_{\text {cor }}\left(10^{\frac{E_{c o r}-E}{b_{a}}}-10^{\frac{E_{c o r}-E}{b_{c}}}\right)$

in order to evaluate the corrosion current density, $\mathrm{j}_{\text {cor }}$ and the anodic and cathodic Tafel slopes $\left(b_{a}\right.$ and $\left.b_{c}\right)$ [38].

\subsection{Surface analyses}

A Scanning Electron Microscope (SEM) model ZEISS EVO MA 15, coupled to an Energy Dispersive X-Ray Spectroscopy (EDS) system (Aztec Oxford apparatus, SDD detector, WD $10 \mathrm{~mm}$, EHT $20 \mathrm{kV}$ ), was used to characterise non-polarized samples exposed for $480 \mathrm{~h}$ to the aggressive solutions with and without inhibitors. Elemental EDS analyses were performed on large surface areas $\left(1.0 \times 0.5 \mathrm{~mm}^{2}\right)$ in order to determine the $\mathrm{Cu} / \mathrm{Sn} \mathrm{wt} \%$ ratio before and after exposure to assess the extent of decuprification in each condition.

In addition to this elemental surface investigation, Raman and XPS spectroscopies were also performed to characterize the sample surfaces.

The Raman spectrometer used was a Renishaw InVia connected to a Renishaw SCA (Structural and Chemical Analyzer). The spectra were collected with an $\mathrm{Ar}^{+}$laser $(\lambda=514.5 \mathrm{~nm})$ and power output less than or equal to $5 \mathrm{~mW}$, to avoid surface degradation.

XPS analyses were carried out on the first atomic layers of the exposed surfaces, using a monochromatized Al-Ka source $(\mathrm{h} \nu=1486.6 \mathrm{eV})$ on a ThermoScientific K-Alpha system. The X-ray spot size was about $400 \mu \mathrm{m}$ in diameter. The photoelectron emission spectra were recorded in direct $\mathrm{N}(\mathrm{Ec})$. The pass energy was fixed at $130 \mathrm{eV}$ with a step of $1 \mathrm{eV}$ for surveys, and $40 \mathrm{eV}$ with a step of $0.1 \mathrm{eV}$ for core levels. Ionic sputtering of the surfaces was made with $\mathrm{Ar}^{+}$ion beam accelerated under $200 \mathrm{eV}$ low current for $30 \mathrm{~s}$, in order to remove carbon surface contamination. XPS data were fitted by using Thermo Scientific $^{\mathrm{TM}}$ Avantage Software and Shirley method was used for the background subtraction of all the peaks. Prior to testing, the samples were stored under $\mathrm{N}_{2}$ to avoid any surface alteration. 
SITP,

2-(Salicylideneimino) thiophenol

SIAP,

2-(Salicylideneimino) aminophenol

MSITP,

2-(3-Methoxy-Salicylideneimino) thiophenol

PMSI,

N,N'-O-phenylen-Bis(3-Methoxy-

Salicylideneimine)<smiles>Oc1ccccc1/C=N\c1ccccc1S</smiles><smiles>Nc1ccccc1/N=C\c1ccccc1O</smiles><smiles>COc1cccc(/C=N\c2ccccc2F)c1O</smiles><smiles>COc1cccc(/C=N/c2ccccc2/N=C/c2cccc(OC)c2O)c1O</smiles>

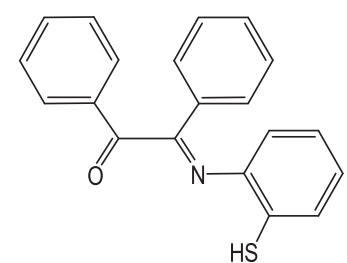

Fig. 1. Structural formulas of the Schiff bases studied as bronze corrosion inhibitors.

\section{Results}

\subsection{Polarization curves}

The polarization curves recorded after $1 \mathrm{~h}$ immersion in uninhibited and inhibited solutions are reported in Fig. 2a and b. In uninhibited ARX10 (blank solution), bronze exhibited a low corrosion current density ( $j_{\text {cor }}$ of the order of $1 \mu \mathrm{Acm}^{-2}$ ) and a relatively high anodic slope up to about $0.01 \mathrm{~V}$, suggesting the presence of a rather continuous and protective oxide film which is most likely to be a residual of the air- formed one. At $0.01 \mathrm{~V}$, an abrupt anodic slope change occurred denoting the breakdown of the passive film, followed by fast bronze dissolution. The cathodic reaction sustaining bronze corrosion was oxygen reduction, which was under activation control at the corrosion potential, $\mathrm{E}_{\mathrm{cor}}$, and reached a limiting reduction current after about $200 \mathrm{mV}$ of cathodic polarization. This indicated that the surface film on bronze sustained a relatively slow charge transfer process controlling oxygen reduction reaction.

Fig. 2a shows that the addition of SITP, MSITP and TPIE determined a significant inhibiting effect on the cathodic reaction, shifting $\mathrm{E}_{\text {cor }}$

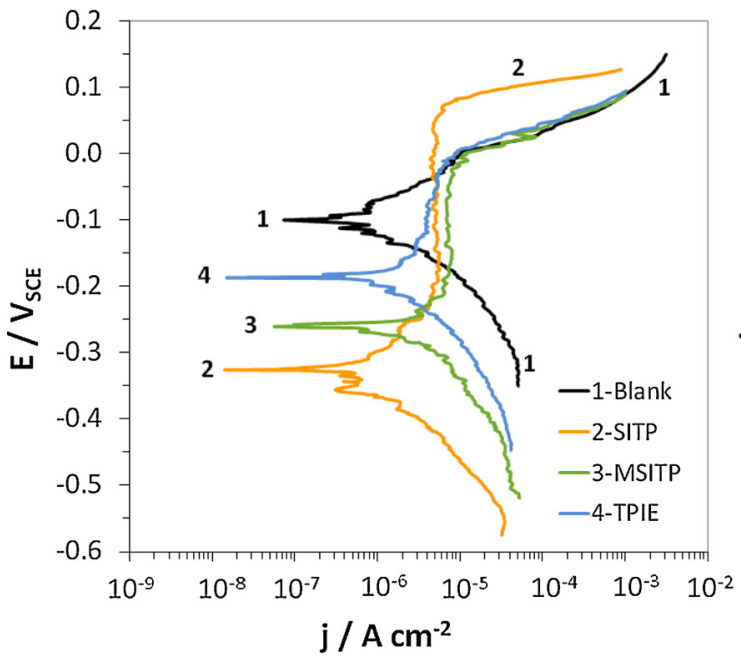

a.

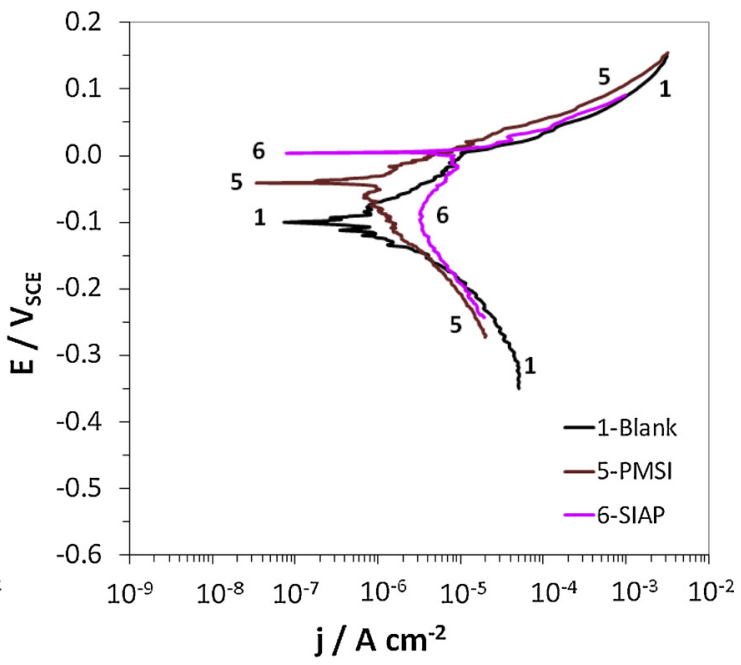

b.

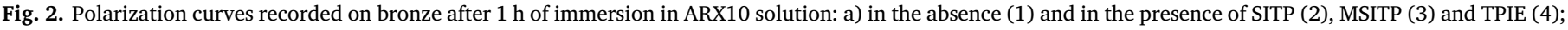
b) in the absence (1) and in the presence of PMSI (5) and SIAP (6). 


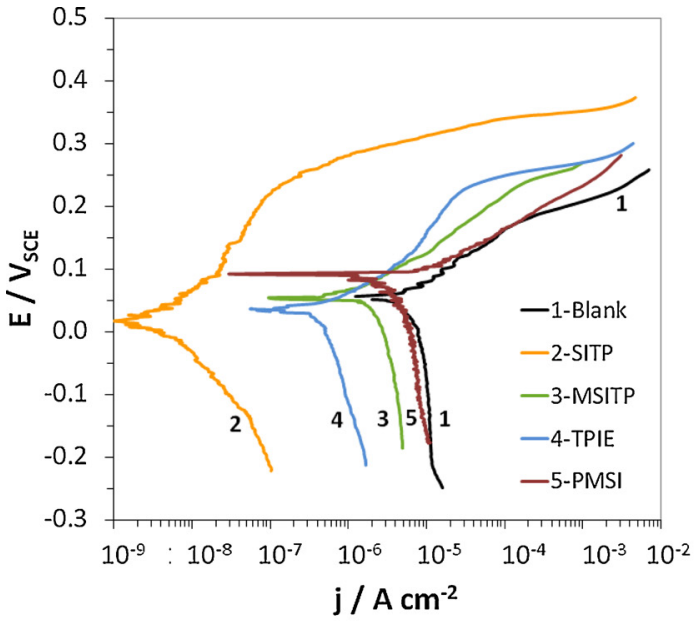

a.

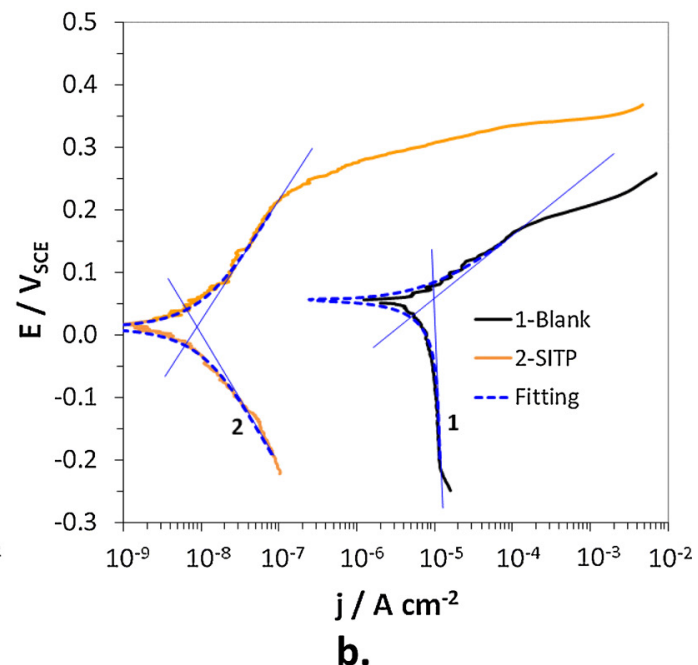

b.

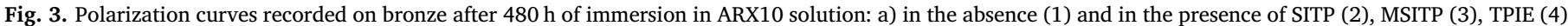
and PMSI (5); b) comparison of experimental and calculated E/j curves to evaluate the corrosion current density, jcor.

values towards negative values. These Schiff bases also widened the passive potential range, but MSITP and TPIE did not increase the potential of film breakdown (about $0.01 \mathrm{~V}$ ) while SITP ennobled it to $0.10 \mathrm{~V}$, determining a passive potential range of about $400 \mathrm{mV}$. On the contrary, PMSI (Fig. 2b) did not significantly modify the corrosion process in comparison to that observed in the blank solution, and slightly reduced the width of the passive potential range. Finally, the addition of SIAP (Fig. 2b) stimulated the cathodic process and accelerated the corrosion of bronze due to the shift of $\mathrm{E}_{\text {cor }}$ up to the potential of film breakdown. Consequently, the test in this last solution was not prolonged over $24 \mathrm{~h}$.

The polarization curves recorded after $480 \mathrm{~h}$ immersion in the absence and in the presence of the Schiff bases except for SIAP are shown in Fig. 3a, while Table 1 reports the electrochemical parameters derived from these curves. In particular, the Table collects the $E_{\text {cor }}$ and $j_{\text {cor }}$ values, the anodic and cathodic Tafel slopes, $b_{a}$ and $b_{c}$, and the inhibiting efficiency values ( $\eta$ ), evaluated by the following formula:

$\eta=\frac{\mathrm{j}_{\text {cor,u }}-\mathrm{j}_{\text {cor,i }}}{\mathrm{j}_{\text {cor }, \mathrm{u}}} \times 100$

where $\mathrm{j}_{\text {cor, } \mathrm{u}}$ and $\mathrm{j}_{\mathrm{cor}, \mathrm{i}}$ refer to the corrosion current density evaluated in uninhibited and inhibited solutions, respectively, by applying the Levenburg-Marquardt (LEV) method and Eq. (1). As an example, in the case of ARX10 in the absence and in the presence of SITP Fig. 3b shows the comparison between the experimental and calculated polarization curves obtained by fitting. Some limited discrepancies were detected due to noise introduced by ohmic drop compensation, especially around $\mathrm{E}_{\mathrm{cor}}$. However, the overall agreement achieved may be considered quite acceptable considering the scope of this research.
Fig. 3a shows that in the absence of additives, the anodic and cathodic currents were higher than those recorded at short immersion times (Fig. 2). The cathodic reaction of oxygen reduction was under mass transport control at $E_{\text {cor }}$ as indicated by the very high $\left|b_{c}\right|$ value (Table 1) and reached a limit current density of about $10 \mu \mathrm{A} \mathrm{cm}^{-2}$, after about $100 \mathrm{mV}$ of cathodic polarization. The shape of the anodic curve suggests that bronze was covered by a surface layer of corrosion products (patina), which partially protected the alloy up to about $0.170 \mathrm{~V}$, where a slope change suggested a faster dissolution process. Average $\mathrm{j}_{\text {cor }}$ values of about $8.3 \mu \mathrm{A} \mathrm{cm} \mathrm{cos}^{-2}$ could be obtained by application of the non linear fitting method (Table 1 ).

After $480 \mathrm{~h}$ the different Schiff bases showed variable inhibiting effects towards bronze corrosion, as indicated by the range of $j_{\text {cor }}$ and $\eta$ values reported in Table 1 . In general, in spite of their low concentrations three of them (SITP, TPIE and MSITP) exhibited significant $\eta$ values of $99.91,94.6$ and $77.3 \%$, respectively. The most efficient substance, SITP, clearly behaved as a mixed corrosion inhibitor because it afforded a strong inhibition of both the cathodic and the anodic process, with passive conditions maintained up to a breakdown potential of about $+0.23 \mathrm{~V}$, that is about $60 \mathrm{mV}$ higher than that recorded in uninhibited solution. TPIE and MSITP could also hinder both the cathodic process, particularly in the case of TPIE, but also the anodic reaction, with the formation of rather protective surface patinas. In both cases, the anodic curves showed a film breakdown potential close to that recorded in SITP solution. Finally, PMSI negligibly inhibited the reaction of oxygen reduction and the anodic polarization curve exhibited a slope of $64.1 \mathrm{mV}$ decade ${ }^{-1}$, much lower than that recorded in the blank solution.

Since phosphonates and N-containing inhibiting mixtures showed

Table 1

Corrosion potentials $\left(E_{\text {cor }}\right)$, corrosion current densities $\left(j_{c o r}\right)$, anodic and cathodic Tafel slopes $\left(b_{a}, b_{c}\right)$ and inhibiting efficiencies calculated from both $j_{\text {cor }}($ that is $\eta$ ) and from polarization resistance values $\left(\eta_{\mathrm{Rp}}\right)$, after $480 \mathrm{~h}$ of immersion in ARX10 solution, in the absence and in the presence of the Schiff bases. All data are presented with their corresponding standard deviations.

\begin{tabular}{|c|c|c|c|c|c|c|}
\hline & $\begin{array}{l}\mathrm{E}_{\mathrm{cor}} / \\
\mathrm{V}_{\mathrm{SCE}}\end{array}$ & $\begin{array}{l}\mathrm{j}_{\text {cor }} / \\
\mu \mathrm{A} \mathrm{cm}\end{array}$ & $\begin{array}{l}\mathrm{b}_{\mathrm{a}} / \\
\mathrm{mV} \text { decade }\end{array}$ & $\begin{array}{l}\left|b_{c}\right| / \\
m V \text { decade }\end{array}$ & $\begin{array}{l}\eta / \\
\%\end{array}$ & $\begin{array}{l}\eta_{\mathrm{Rp}} / \\
\%\end{array}$ \\
\hline Blank & $0.055 \pm 0.013$ & $8.3 \pm 1.1$ & $90.2 \pm 6.7$ & $\infty$ & - & - \\
\hline SITP & $0.017 \pm 0.015$ & $0.0082 \pm 0.0025$ & $170 \pm 16$ & $200 \pm 13$ & $99.91 \pm 0.03$ & $99.91 \pm 0.04$ \\
\hline TPIE & $0.036 \pm 0.024$ & $0.46 \pm 0.21$ & $76.1 \pm 8.2$ & $420 \pm 58$ & $94.6 \pm 2.3$ & $96.1 \pm 2.5$ \\
\hline PMSI & $0.072 \pm 0.020$ & $5.1 \pm 1.0$ & $64.1 \pm 5.8$ & $\infty$ & $33 \pm 11$ & $36 \pm 21$ \\
\hline SITP + P & $0.078 \pm 0.018$ & $0.018 \pm 0.010$ & $290 \pm 11$ & $270 \pm 14$ & $99.83 \pm 0.09$ & $99.91 \pm 0.04$ \\
\hline $\mathrm{P}$ & $0.024 \pm 0.012$ & $6.0 \pm 1.8$ & $60.2 \pm 7.1$ & $180 \pm 15$ & $19 \pm 18$ & $11 \pm 15$ \\
\hline
\end{tabular}




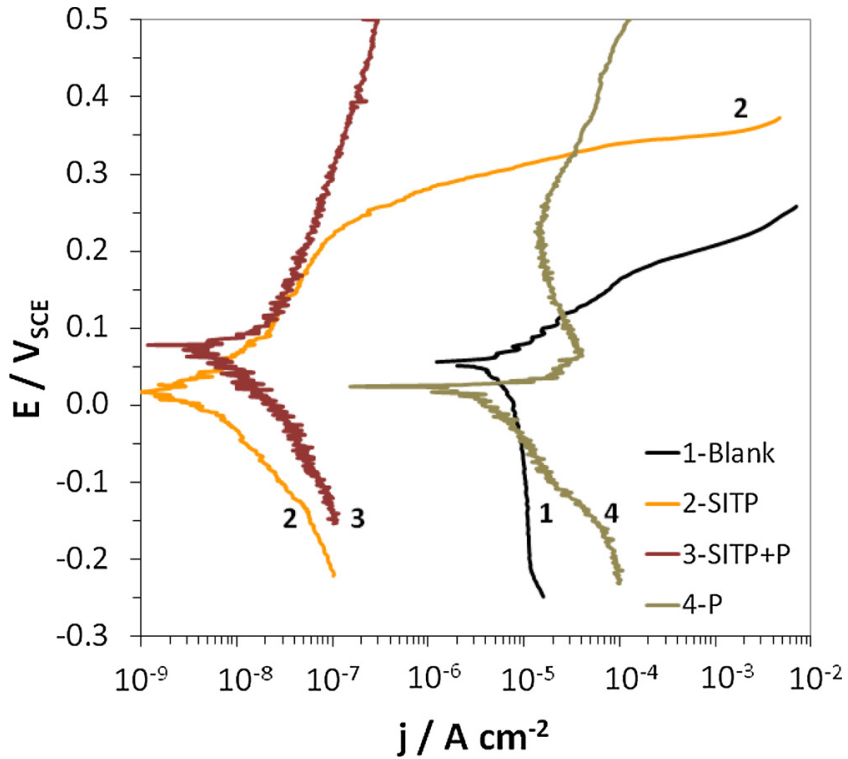

Fig. 4. Polarization curves recorded on bronze after $480 \mathrm{~h}$ of immersion in ARX10 solution in the absence (1) and in the presence of SITP (2), SITP + P (3) and only $\mathrm{P}$ (4).

synergistic inhibition of steel corrosion in chloride solution [34], an attempt was made to assess whether a mixture of saturated SITP and $10^{-2}$ M P would also afford a similar synergistic effect for bronze. For this reason, bronze samples were exposed for $480 \mathrm{~h}$ to ARX10 in the presence of either the SITP $+\mathrm{P}$ mixture or only $\mathrm{P}$ salt. Final polarization curves are collected in Fig. 4, while the electrochemical parameters derived from these polarization curves are collected in Table 1. They show that $\mathrm{P}$ alone negligibly inhibited the cathodic reaction in the vicinity of $\mathrm{E}_{\text {cor }}$, but under anodic polarization the alloy reached a passivation potential at about $+0.07 \mathrm{~V}$, above which a quite steep anodic slope was obtained with currents slowly increasing from 15 to $100 \mu \mathrm{A} \mathrm{cm}^{-2}$ without the onset of pitting attack up to $+0.5 \mathrm{~V}$. The SITP + P mixture was very effective, but did not afford any synergistic inhibition because $\mathrm{j}_{\text {cor }}$ was slightly higher than that obtained with SITP alone (Table 1). However, the mixture induced a stable passive condition on bronze which remained unaltered up to potentials nobler than $+0.5 \mathrm{~V}$.

\subsection{EIS tests}

A nondestructive EIS technique was used to investigate the time evolution of the corrosion process on bronze and to characterize the bronze / aggressive solution interface in ARX10, in the absence and in the presence of the various Schiff bases. In the case of SITP, the influence of $\mathrm{P}$ addition was also studied.

As shown in Fig. 5a and b, the dielectric behavior of bronze exposed to uninhibited ARX10 for periods longer than $1 \mathrm{~h}$ was characterized by three time constants, in accordance with results obtained by other authors in similar environments $[6,39,40]$. In fact, three loops were detected in the Nyquist plots, in the frequency ranges: $10-10^{3} \mathrm{~Hz}$ (highfrequency (HF) loop), $10^{-1}-10 \mathrm{~Hz}$ (medium-frequency (MF) loop), and at frequencies lower than $10^{-1} \mathrm{~Hz}$ (low-frequency (LF) arc).

The spectra were correctly fitted by the equivalent circuit (EC) reported in Fig. 6a, where three nested R-CPE (Resistance-Constant Phase Element) couples were present. As the loops in the spectra were depressed semicircles, CPE elements were used instead of capacitances to compensate for surface roughness, porosities and other surface inhomogeneities. The impedance expression of CPE was $\mathrm{Z}=\left[\mathrm{Y}(\mathrm{jw})^{\mathrm{n}}\right]^{-1}$, where $\mathrm{w}=2 \pi \mathrm{f}$ is the angular frequency, $\mathrm{j}=\mathrm{V}(-1)$ is the imaginary unit, $\mathrm{Y}$ is a frequency independent value and $\mathrm{n}$ is a fit parameter with values
$0 \leq \mathrm{n} \leq 1$, which measure the element deviation from the ideal capacitive behaviour (exhibiting $\mathrm{n}=1$ ) [41-43]. For each R-CPE couple, the general equation $C=\left(R^{1-n} Y\right)^{1 / n}$ was used to convert the $Y$ parameters of the CPE elements into the associated capacitances (with $\mathrm{R}$ being the corresponding couple resistance) $[40,44]$.

Previous studies allow a physical interpretation of the elements in Fig. 6a $[6,39,40,45,46]$. In particular:

- $R_{s}$ is the solution resistance between the bronze electrode and the reference electrode;

- the $R_{f}-C_{f} E_{f}$ couple describes the dielectric properties of a surface corrosion product film (HF time constant), with $\mathrm{R}_{\mathrm{f}}$ and $\mathrm{C}_{\mathrm{f}}$ corresponding to the resistance and pseudocapacitance values of the surface film;

- the $R_{t}-C_{\mathrm{CP}}$ couple is correlated to the charge transfer reaction occurring on bronze (MF time constant) and $\mathrm{R}_{\mathrm{t}}$ and $\mathrm{C}_{\mathrm{dl}}$ are the charge transfer resistance and the capacitance of the double layer at the metal-electrolyte interface;

- the $\mathrm{R}_{\mathrm{F}}-\mathrm{CPE}_{\mathrm{F}}$ pair (LF time constant) refers to the faradaic reactions of oxidation - reduction involving the surface corrosion products (likely related to the redox reaction between $\mathrm{Cu}$ and $\mathrm{Cu}(\mathrm{I})$ ions, the latter incorporated into the surface film based on cuprite, $\mathrm{Cu}_{2} \mathrm{O}$, in the blank solution); therefore $\mathrm{R}_{\mathrm{F}}$ and $\mathrm{C}_{\mathrm{F}}$ are the resistance of the faradaic reactions and the related pseudocapacitance value, respectively.

The $\mathrm{n}$ exponent values in CPE analytical expressions used to fit the depressed features of experimental Nyquist plots fall within the range $0.54-1$, in analogy to previous results achieved on bronze in uninhibited and inhibited synthetic acid rain [6,39,47].

The evolution of the bronze corrosion behavior in uninhibited ARX10 can be interpreted by discussing the EIS fitting results, also in the light of the trends shown by the polarization curves (Figs. 2 and 3).

First af all, Fig. 5a shows a time evolution of the solution resistance values $\left(R_{s}\right.$, corresponding to the high frequency intercept of the spectra with the real axis). In fact, from 1 to $48 \mathrm{~h}$ of immersion, $R_{s}$ passed from 500 to about $800 \Omega \mathrm{cm}^{2}$, due to a concomitant solution $\mathrm{pH}$ increase from 3.3 to about 5.3, induced by the oxygen reduction reaction sustaining corrosion. At even longer immersion times (Fig. $5 b$ ), $R_{s}$ values remained more or less constant because of the buffering effect of dissolved copper cations determining a $\mathrm{pH}$ stabilization.

After $1 \mathrm{~h}$ immersion in ARX10, only the MF and LF time constants were distinguished in the EIS spectrum (Fig. 5a, inset), suggesting that the surface film had a negligible effect on the electrode impedance. The $\mathrm{R}_{\mathrm{f}}-\mathrm{CPE}_{\mathrm{f}}$ couple was, therefore, omitted and the EC adopted is that reported in Fig. 6b. The results of the best fitting procedure are also included in Fig. 5. Quite similar results have been obtained by other authors in comparable environments $[6,46]$. The fitting parameters are reported in Fig. 7, together with the $R_{p}$ values calculated as the sum: $R_{p}$ $=R_{f}+R_{t}+R_{F}$ [40,46-49]. Although at $1 \mathrm{~h}$ immersion a clear time constant related to the surface film was not detected, bronze exhibited a passive behaviour as evidenced by the high anodic slope in the $1 \mathrm{~h}$ anodic polarization curve (Fig. 2). The surface film, likely residual of the air-formed oxide film, determined a relatively high charge transfer resistance (a high $R_{t}$ at $1 \mathrm{~h}$ immersion), thus justifying the low cathodic currents in the blank polarization curves of Fig. 2 [37]. At increasing immersion times, the film underwent a fast alteration in contact with the aggressive solution because after $2 \mathrm{~h}$ immersion $R_{t}$ and $R_{p}$ had already shown a significant decrease.

Until about $260 \mathrm{~h}$, rather low and constant $R_{f}$ and $R_{t}$ values were achieved. They then tended to increase slightly with time as a consequence of the accumulation of corrosion products hindering the alloy oxidation. This was in agreement with the shape of the anodic polarization curve recorded on bronze after $480 \mathrm{~h}$ of immersion (Fig. 3), which exhibited a relatively high anodic slope of $90.2 \mathrm{mV} /$ decade. The decrease in $\mathrm{C}_{\mathrm{f}}$ pseudocapacitance values after $360 \mathrm{~h}$ confirmed the 


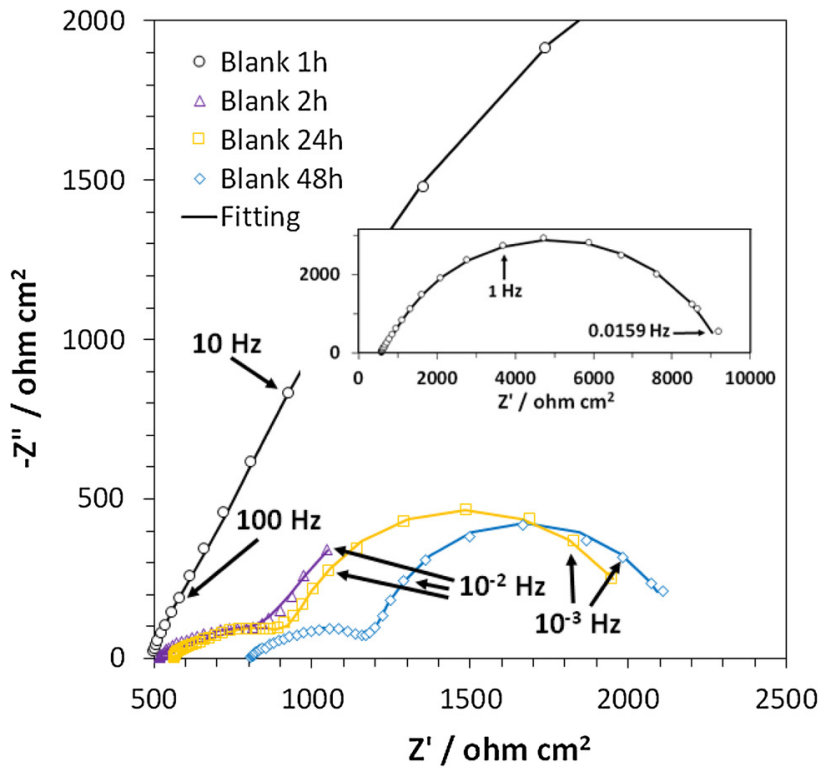

a.

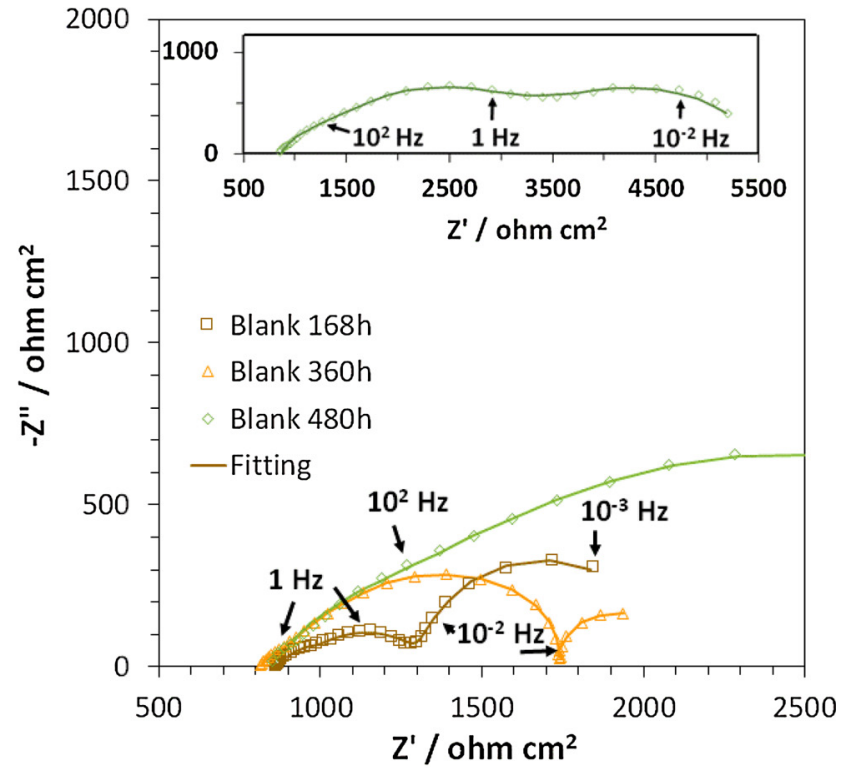

b.

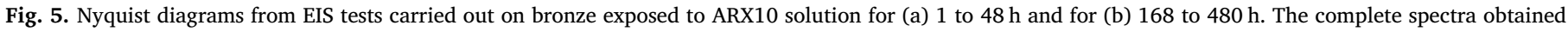
after $1 \mathrm{~h}$ and $480 \mathrm{~h}$ are shown in the insets.

increase in film thickness at long immersion times, while the $\mathrm{C}_{\mathrm{dl}}$ diminution, particularly in the second half of the immersion, was most likely a consequence of the decrease in the surface area of the active anodic regions under the surface film.

$\mathrm{R}_{\mathrm{F}}$, connected to the resistance of the faradaic reaction of interchange between $\mathrm{Cu}$ and $\mathrm{Cu}(\mathrm{I})$, significantly decreased during most of the immersion period because the $\mathrm{Cu}_{2} \mathrm{O}$ film, which is expected to have a high faradaic activity, grew on the surface and caused an increase in region areas where the reaction may occur. A final increase in $R_{F}$ trend may have been connected to the final decrease in film porosity with a consequent decrease in the electrolyte accessibility to the metal/ $\mathrm{Cu}_{2} \mathrm{O}$ interface. This variation of the metal/ $\mathrm{Cu}_{2} \mathrm{O}$ interface area also affected $\mathrm{C}_{\mathrm{F}}$ which accordingly showed an opposite trend to $\mathrm{R}_{\mathrm{F}}$, in particular an initial fast, followed by a slow increase and a final decrease.

In SITP solution, due to the strong inhibition of the corrosion process, a limited $\mathrm{pH}$ variation was detected during bronze immersion (final $\mathrm{pH}$ values $=3.5$ ) and consequently rather constant $\mathrm{R}_{\mathrm{s}}$ values (in the range $450-550 \mathrm{ohm} \mathrm{cm}^{2}$ ) were measured. With this very efficient inhibitor only the HF and MF loops were detected, while the LF loop connected to the faradaic reactions was absent at all immersion times. This suggests that the inhibitor adsorption produces a highly stable surface film with low $\mathrm{Cu}(\mathrm{I}) \leftrightarrows \mathrm{Cu}$ reactivity. The evolution of the SITP spectra is shown in Fig. 8a, which clearly evidences an increase in bronze corrosion resistance during time. The two time constant-EC reported in Fig. $6 \mathrm{c}$ was used for curve fitting and the parameters achieved by data interpolation are reported in Fig. 7, where they can be compared to those in the blank solution. The high and increasing corrosion resistance of bronze was connected to a high $\mathrm{R}_{t}$ which rose up to about $5 \mathrm{M} \Omega \mathrm{cm}^{2}$ and to $\mathrm{R}_{\mathrm{f}}$, which increased with time by more than two orders of magnitude and finally reached a value over $1 \mathrm{M} \Omega \mathrm{cm}^{2}$. This suggests that SITP appears to produce a protective surface film which hinders charge transfer from the very beginning of the immersion. The concomitant limited decrease in $\mathrm{C}_{\mathrm{f}}$ pseudocapacitance values suggests that the thickness of the SITP film grows only slightly with time and its increasing resistance is likely connected to a progressively more compact and resistive nature. $\mathrm{C}_{\mathrm{dl}}$ decreased by one order of magnitude with time, which may reasonably be put down to a decrease in surface area on which charge transfer may occur while the film density increases and/or to a progressive substitution of water molecules (with high dielectric constant) by adsorbed organic inhibitor molecules (with low dielectric constant) within the double layer.

Given its interesting anodic behavior, the inhibition mechanism of the mixture SITP + P was also investigated by means of EIS spectra fitting. In this case, during bronze immersion no $\mathrm{pH}$ variation and rather constant $R_{s}$ values were detected. These latter values were lower than those measured in SITP solution (about $200 \Omega \mathrm{cm}^{2}$ ), due to the presence of $10^{-2} \mathrm{M} \mathrm{P}$ (sodium dihydrogen phosphate salt). Selected spectra among those recorded during the $480 \mathrm{~h}$ immersion period are presented in Fig. $8 \mathrm{~b}$. They are quite different from those recorded in the presence of SITP alone, as they are again best fitted by the three time constant-EC of Fig. 6a. Therefore, although in this solution bronze underwent a much slower corrosion process than in the blank, the electrode impedance was affected by the same contributions found in the blank solution: the dielectric properties of a surface film, a charge transfer process at the electrode surface and a faradaic reaction involving the surface film. The fitting parameters can be compared to those obtained in the presence of SITP alone and in the blank solution in Fig. 7.

Within $72 \mathrm{~h}$ of immersion, $\mathrm{R}_{\mathrm{f}}$ was higher than in SITP solution (values around $40-50 \mathrm{k} \Omega \mathrm{cm}^{2}$ ) and then set at about $30 \mathrm{k} \Omega \mathrm{cm}^{2}$. These

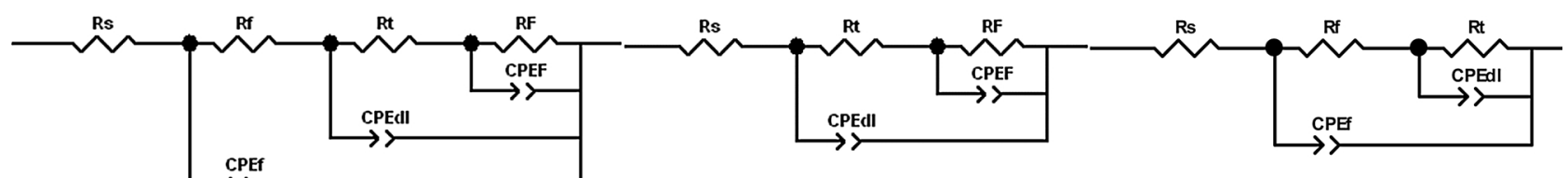

a.

b.

c.

Fig. 6. Equivalent circuits (EC) with three (a) or two (b, c) time constants, used to fit the experimental EIS spectra. 


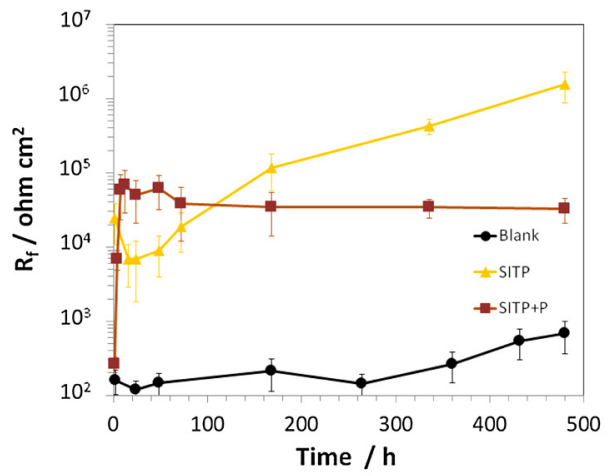

a.

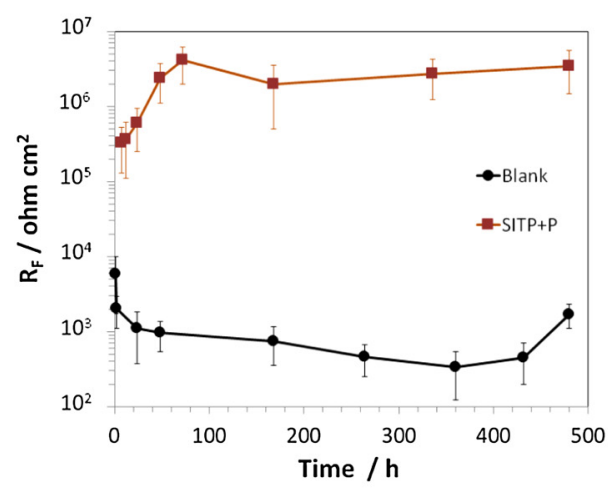

c.

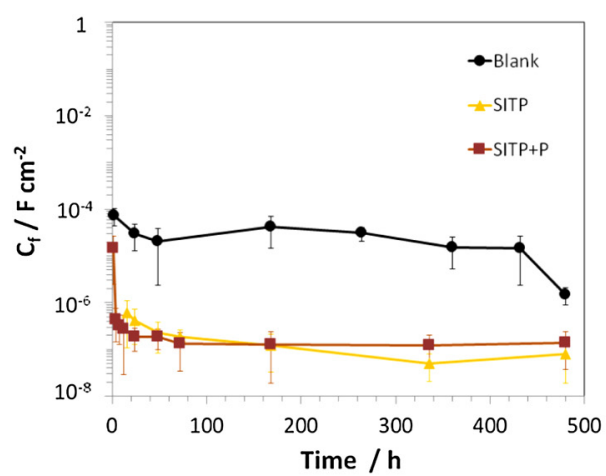

e.

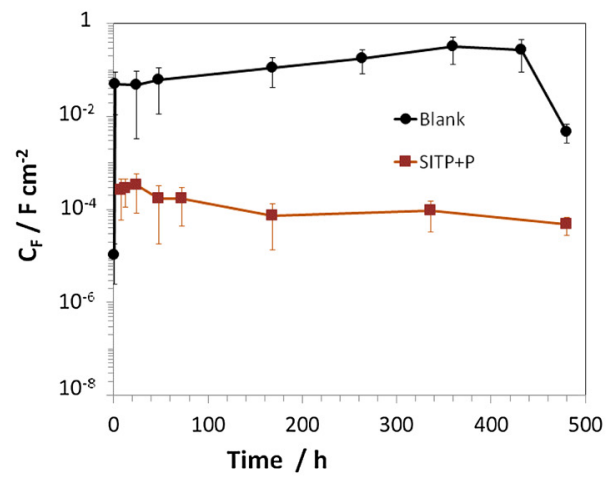

g.

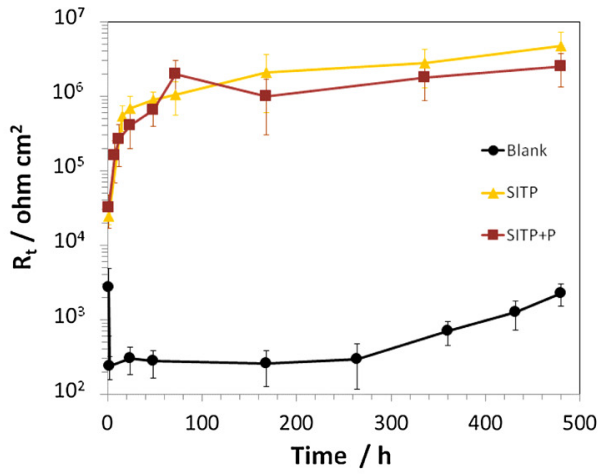

b.

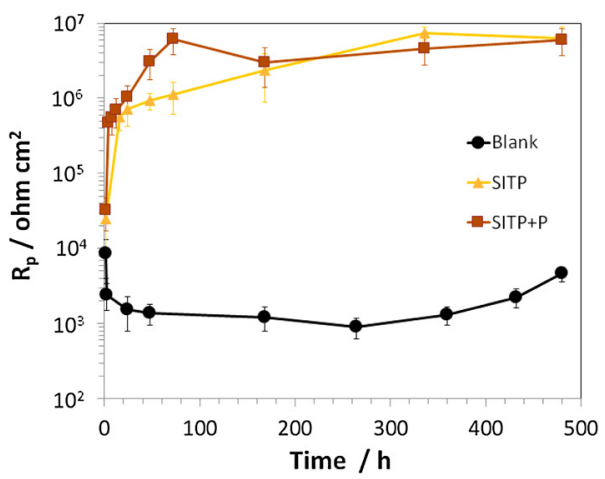

d.

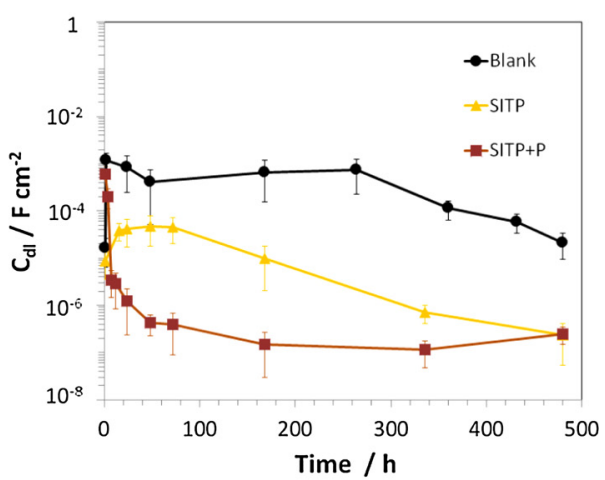

f. presence of SITP and SITP $+\mathrm{P}$ 


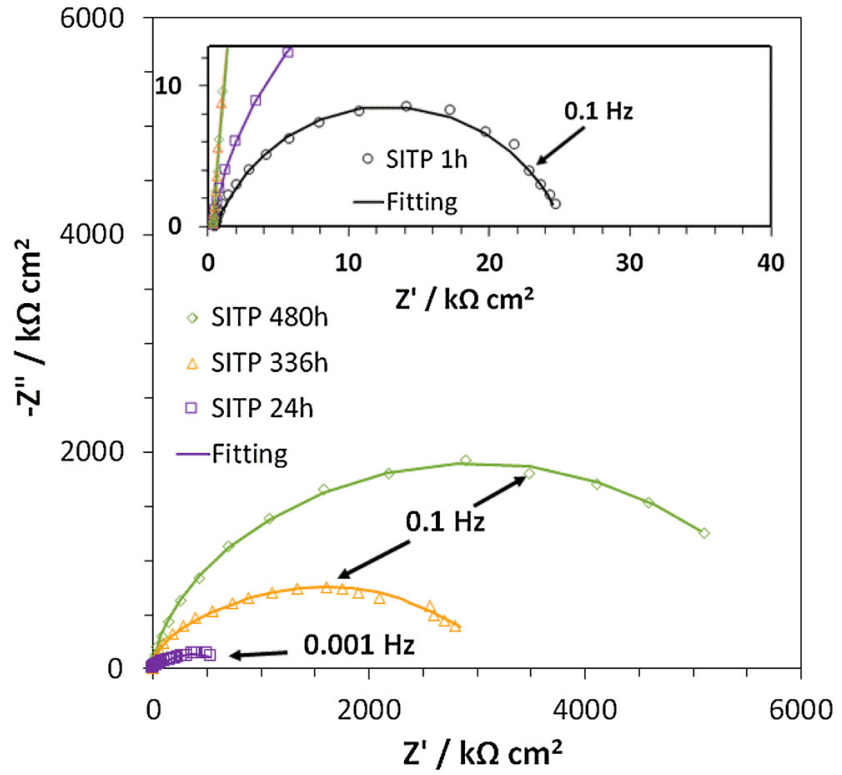

a.

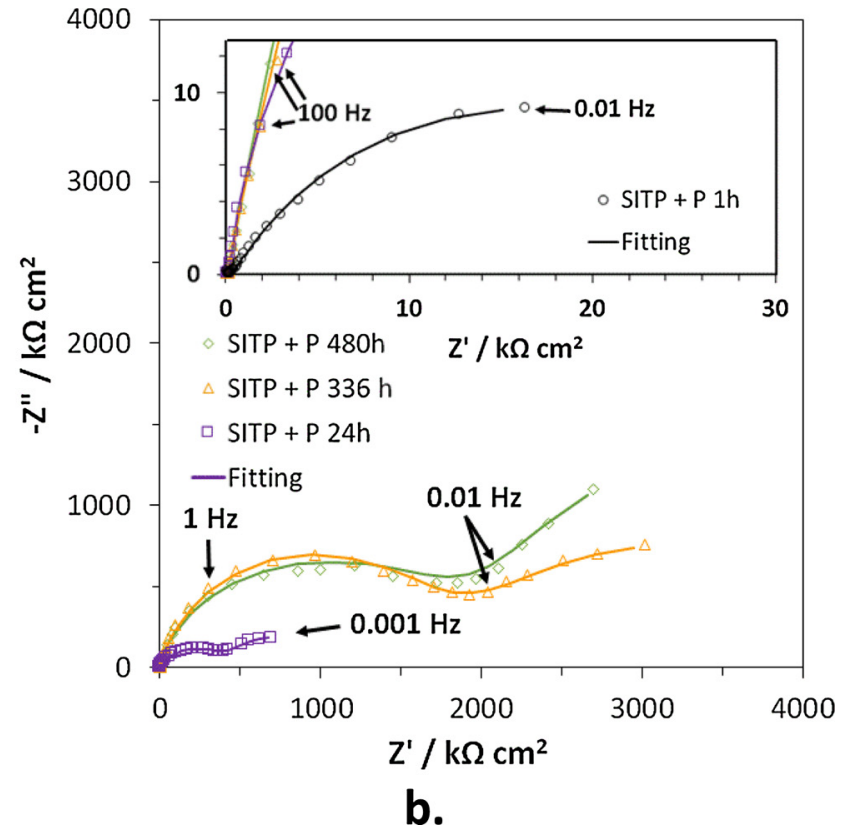

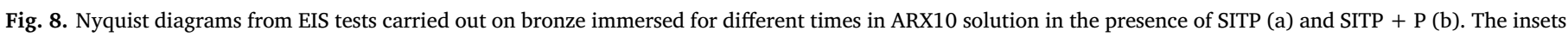
show the complete spectra obtained after $1 \mathrm{~h}$ in the presence of SITP (a) and SITP + P (b).

final values were more than one order of magnitude lower than the final ones achieved in SITP solution, while only slightly lower $R_{t}$ values were obtained, setting at about $1 \mathrm{M} \Omega \mathrm{cm}^{2}$. $\mathrm{R}_{\mathrm{F}}$ was always higher than $\mathrm{R}_{\mathrm{t}}$ and followed the same $R_{t}$ trend. The presence of the $R_{F}-C_{F}$ couple in the EC suggests that in SITP + P solution the film exhibits a faradaic activity, but is less susceptible to redox processes than in the blank solution, as indicated by much higher $\mathrm{R}_{\mathrm{F}}$ and much lower $\mathrm{C}_{\mathrm{F}}$ values. Within the initial 2-3 days of exposure, $C_{f}$ and $C_{d l}$ decreased slowly and then remained more or less constant, suggesting a limited increase in the film thickness and a contemporary decrease in the metal surface area available for charge transfer. All these findings indicate that the addition of $\mathrm{P}$ to SITP solution changed the characteristics of the surface film. In particular, even at short immersion times $\mathrm{P}$ contributed to producing a resistive film which did not then evolve significantly. Although this film maintained a low faradaic activity it was higher than that of the SITP film. In general, these variations induced high $R_{p}$ values (Fig. $7 d$ ), even higher than those presented by SITP alone within 3 days of immersion, but, in accordance with polarization curve results, they were comparable to those obtained by SITP during long immersion times.

With the exception of SITP, the other Schiff bases showed EIS spectra with three time constants, like those in the blank solution, and could be fitted with the EC in Fig. 6a. As an example, Fig. 9 shows the agreement between the experimental spectra obtained in the presence of the Schiff bases at the end of the immersion period and those obtained by the fitting procedures $\left(\chi^{2}\right.$ values $\left.\leq 0.0007\right)$.

The $R_{p}$ (calculated as the sum of $R_{f}, R_{t}$ and $R_{F}$ ) and the corresponding $\mathrm{E}_{\mathrm{cor}}$ values obtained on bronze with time in the absence and presence of all Schiff bases are reported in Fig. 10.

In comparison to the blank, SIAP addition did not modify bronze corrosion behavior in ARX10 (as also indicated by the spectrum in the inset of Fig. 9); this was likely due to its low concentration and scarce adsorption capability. Instead, TPIE and MSITP, but also PMSI to a limited extent, presented an inhibition effect, in agreement with the results of the polarization curves. The concurrent $\mathrm{E}_{\mathrm{cor}}$ evolution exhibited quite negative initial values, often more active than those in the blank, suggesting that they initially acted as cathodic inhibitors. Their surface films then became more protective and their $\mathrm{E}_{\text {cor }}$ values reached and exceeded those in the blank solution. In conclusion, as also indicated by the recorded polarization curves, SITP, TPIE and MSITP act

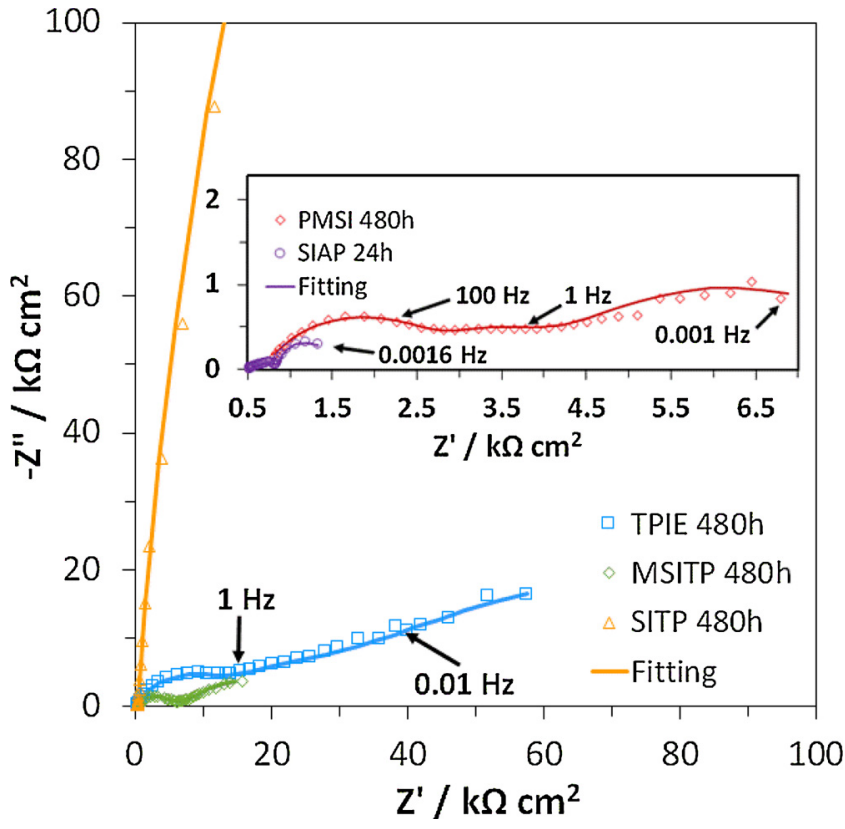

Fig. 9. Nyquist diagrams from EIS tests carried out on bronze immersed for $480 \mathrm{~h}$ to ARX10 solution in the presence of the different Schiff bases. In the case of SIAP (inset), the spectrum was recorded after $24 \mathrm{~h}$ of immersion.

as mixed corrosion inhibitors.

The inhibiting efficiencies of the Schiff bases and SITP $+\mathrm{P}$ formulation after $480 \mathrm{~h}$ immersion calculated from $R_{p}$ values $\left(R_{p, i}\right.$ in inhibited and $R_{p, u}$ in uninhibited blank solutions) by the formula:

$\eta_{R_{p}}=\frac{\mathrm{R}_{\mathrm{p}, \mathrm{i}}-\mathrm{R}_{\mathrm{p}, \mathrm{u}}}{\mathrm{R}_{\mathrm{p}, \mathrm{i}}} \times 100$

are given in Table 1. They are in overall good agreement with those achieved from polarization curve analysis and confirm them. 


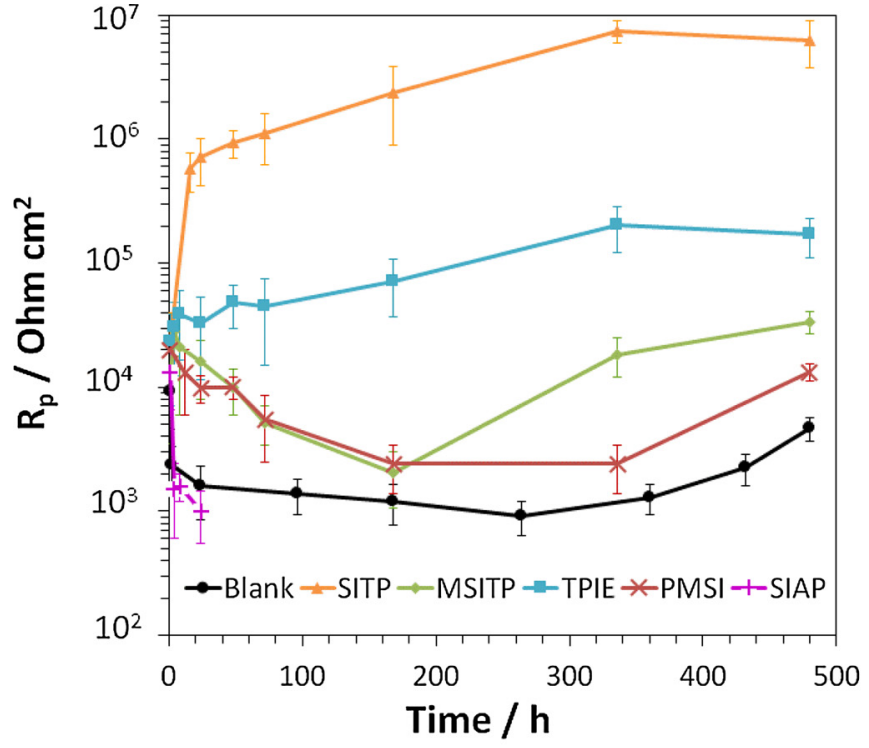

a.

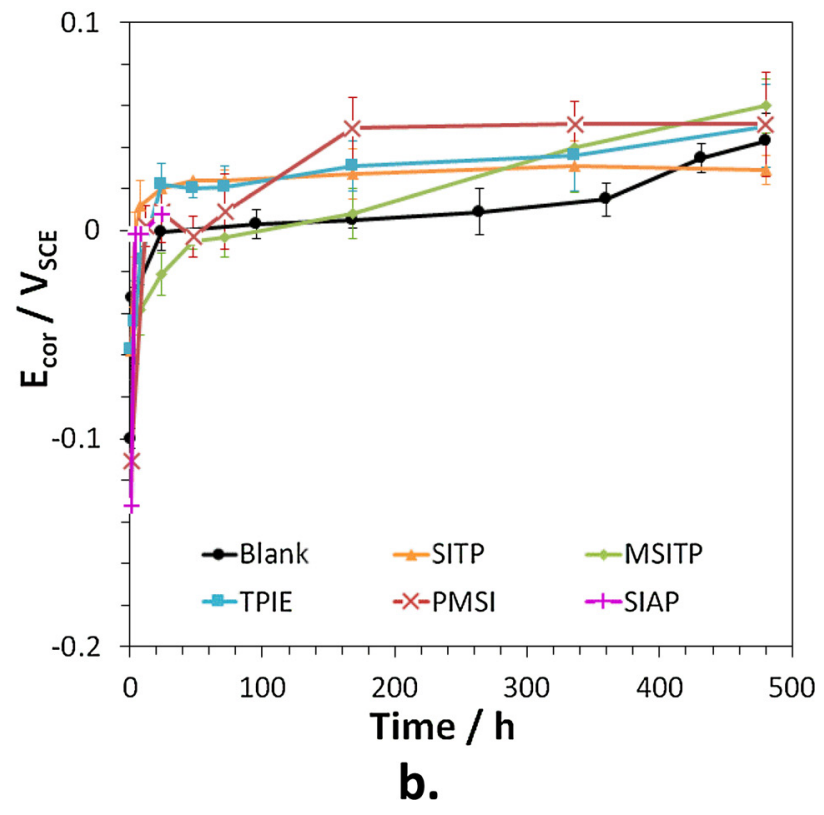

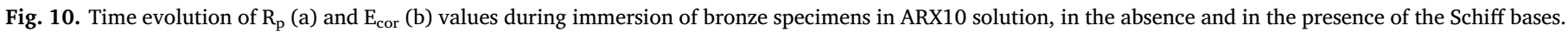

\subsection{SEM-EDS analysis}

Fig. 11 collects SEM observations obtained on unexposed bronze samples and on samples after $1 \mathrm{~h}$ or $480 \mathrm{~h}$ of immersion in ARX10 solution, both in the absence of inhibitors and in the presence of SITP or SITP + P. Fig. 11a, related to unexposed bronze, clearly shows that the alloy was an $\alpha$-cored bronze with dendritic microstructure, with Sn- an Sb- local enrichment also revealing the Pb globules (white spots in the BSE image of Fig. 11a) in the interdendritic regions.

In ARX10 the corrosion of uninhibited bronze (Fig. 11b and c) was significant and mainly localized in the core of dendritic regions and at $\mathrm{Pb}$ globules. The latter attack is more visible at short immersion times (Fig. 11b), where many small black holes were visible in the interdendritic region, due to the dissolution of the white $\mathrm{Pb}$ globules clearly evident on unexposed bronze (Fig. 11a). This behavior is in agreement with the lower nobility of $\mathrm{Pb}$ in comparison to $\mathrm{Cu}$, as assessed during tests on pure metals in ARX10 [35]. The corrosion attack was quite limited in SITP solution (Fig. 11d and e). In this case, only partial $\mathrm{Pb}$ globule dissolution occurred at long immersion times leaving a few small holes in the corresponding areas. In the presence of the SITP $+\mathrm{P}$ inhibiting mixture (Fig. 11f and g), the corrosion attack was also very light and, at the end of the immersion, was localized on $\mathrm{Pb}$ while the visible dendritic aspect vanished.

Overall, the SEM-EDS analysis after $480 \mathrm{~h}$ of immersion revealed the presence of chlorides at a concentration of $0.3 \pm 0.1 \mathrm{wt} . \%$ on the surface of the sample exposed to non-inhibited solution, while in the presence of SITP and SITP $+P$ these aggressive anions were not detectable. Moreover, in the absence of inhibitors, the phenomenon of decuprification took place on the bronze surface with a reduction in the $\mathrm{Cu} / \mathrm{Sn}$ wt.\% ratio from 34.3 (before exposure) to 15.1 (after $480 \mathrm{~h}$ of exposure to ARX10). Instead, after $480 \mathrm{~h}$ in the presence of inhibitors, this ratio remains equal to 34.3 in the presence of SITP, and was slightly reduced to 29.4 in the presence of SITP + P. This confirms the lower dissolution of copper from the alloy in the presence of SITP or SITP $+\mathrm{P}$ compared to the blank solution.

\subsection{Raman spectroscopy}

Raman spectroscopy performed on bronze exposed for $480 \mathrm{~h}$ in ARX10 confirmed the presence of typical products found in outdoor bronze patinas. Large crystals of $\mathrm{Cu}_{2} \mathrm{O}$ and few isolated crystals of posnjakite $\left(\mathrm{Cu}_{4}\left(\mathrm{SO}_{4}\right)(\mathrm{OH})_{6} \cdot\left(\mathrm{H}_{2} \mathrm{O}\right)\right)$ were found in the core of dendrites, while $\mathrm{Cu}_{2} \mathrm{O}$ and traces of nanocrystalline $\mathrm{SnO}_{\mathrm{x}} \cdot\left(\mathrm{H}_{2} \mathrm{O}\right)_{\mathrm{y}}$ were detected in the interdendritic regions.

Raman spectra on SITP-protected bronze showed very pronounced fluorescence bands, suggesting the presence of a surface film containing the organic inhibitor. Also in the case of SITP + P, the Raman spectra were poorly readable, due to the presence of intense fluorescence bands.

\subsection{XPS spectroscopy}

In order to obtain information on the inhibition mechanism occurring on bronze, the XPS technique was applied on unexposed samples and on samples exposed for $480 \mathrm{~h}$ to ARX10, both in the absence and in the presence of SITP or SITP + P.

As regards the unexposed bronze, the surface XPS analysis (survey in Fig. 12a) detected the presence of $\mathrm{Cu}, \mathrm{Pb}$ and $\mathrm{Sn}$ among the alloying elements, and $\mathrm{C}$ and $\mathrm{O}$ as environmental contaminants. The presence of $\mathrm{Zn}$ or $\mathrm{Sb}$ was not highlighted. By analyzing the areas of the deconvoluted profiles in the high-resolution spectra (core levels, in Fig. 13), it was possible to quantify each peak component in atomic percentages, as summarized in Table 2, together with the corresponding binding energies (BE) [36]. $\mathrm{Cu}$ and $\mathrm{Sn}$ were detected on the surface both in the metallic and oxidized state (Table 2 ) while $\mathrm{Pb}$ was mainly present as an oxide, suggesting that surface polishing and air oxidation produces a thin film of corrosion products. $\mathrm{Cu} 2 \mathrm{p}$ core level and Auger spectra $(\mathrm{Cu}$ LMM) are reported in Fig. 13e and f, respectively. The former spectrum showed a high peak at $932.5 \mathrm{eV}$ and no shake-up satellite peak at 940-944 eV, suggesting the possible presence of $\mathrm{Cu}(\mathrm{I})$ and/or $\mathrm{Cu}(0)$ [50,51]. The Auger $\mathrm{Cu} \mathrm{L}_{3} \mathrm{M}_{4,5} \mathrm{M}_{4,5}$ signals at $916.8 \mathrm{eV}$ and $918.7 \mathrm{eV}$ (Kinetic Energy, KE) well corresponded to a mix of $\mathrm{Cu}(\mathrm{I})$ and $\mathrm{Cu}(0)$ species, respectively [50,52]. Fig. $13 \mathrm{~g}$ shows quite small Sn3d signals $\left(\mathrm{Sn}_{3} \mathrm{~d}_{5 / 2}\right.$ at $486 \mathrm{eV}$ and $\mathrm{Sn} 3 \mathrm{~d}_{3 / 2}$ at $494 \mathrm{eV}$ ). The deconvolution of $\mathrm{Sn}$ $3 d_{5 / 2}$ (Fig. 13g) suggested the concomitant presence of $\operatorname{Sn}(0)$ at $4847 \mathrm{eV}$ and $\mathrm{Sn}$ (II) at $4858 \mathrm{eV}$, both in negligible amounts (Table 2) [53-57]. Instead, the core level spectrum of $\mathrm{Pb} 4 \mathrm{f}$ (Fig. 13h) showed a peak at $138.1 \mathrm{eV}\left(\mathrm{Pb} \mathrm{f}_{7 / 2}\right)$ to be ascribed to oxidized $\mathrm{Pb}$ and revealed that no metallic $\mathrm{Pb}$ was present on the surface $[58,59]$. This film constituted of limited $\mathrm{Cu}(\mathrm{I}), \mathrm{Sn}(\mathrm{II})$ and $\mathrm{Pb}$ oxide species was most likely still present on bronze after $1 \mathrm{~h}$ immersion in ARX10 and was responsible for the significant bronze corrosion resistance shown by the 


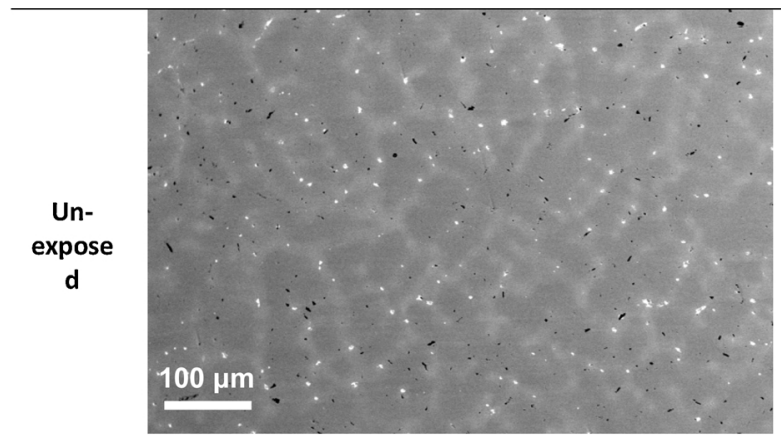

a.

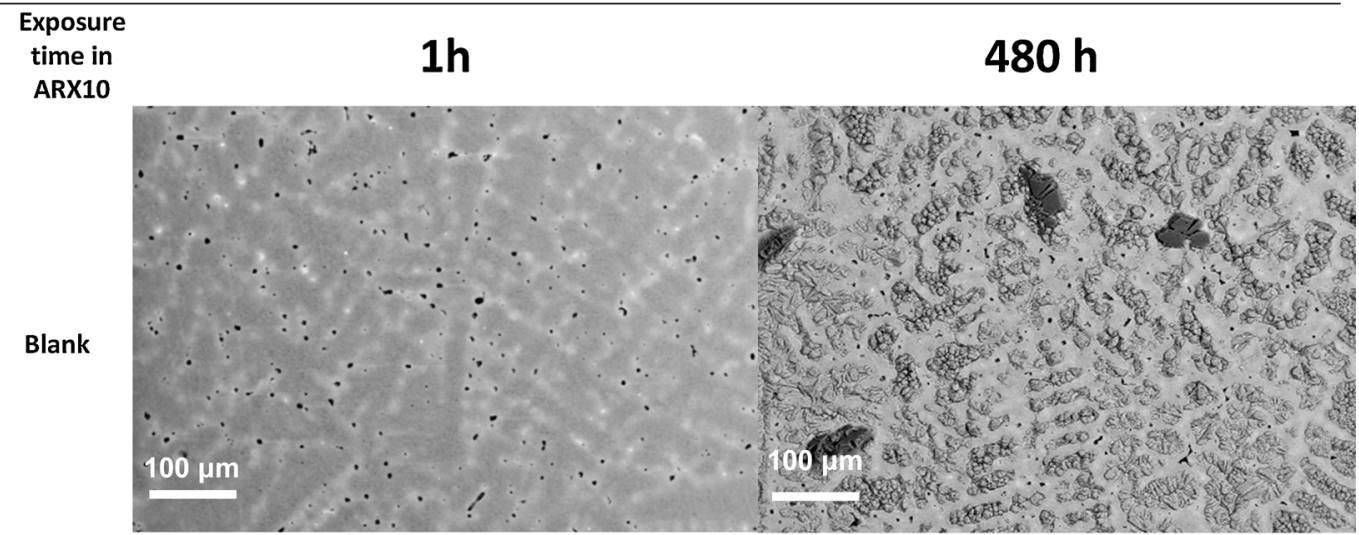

b.

c.

\begin{tabular}{lll}
\hline $\begin{array}{l}\text { Exposure } \\
\text { time in } \\
\text { ARX10 }\end{array}$ & $1 \mathrm{~h}$ & $480 \mathrm{~h}$
\end{tabular}

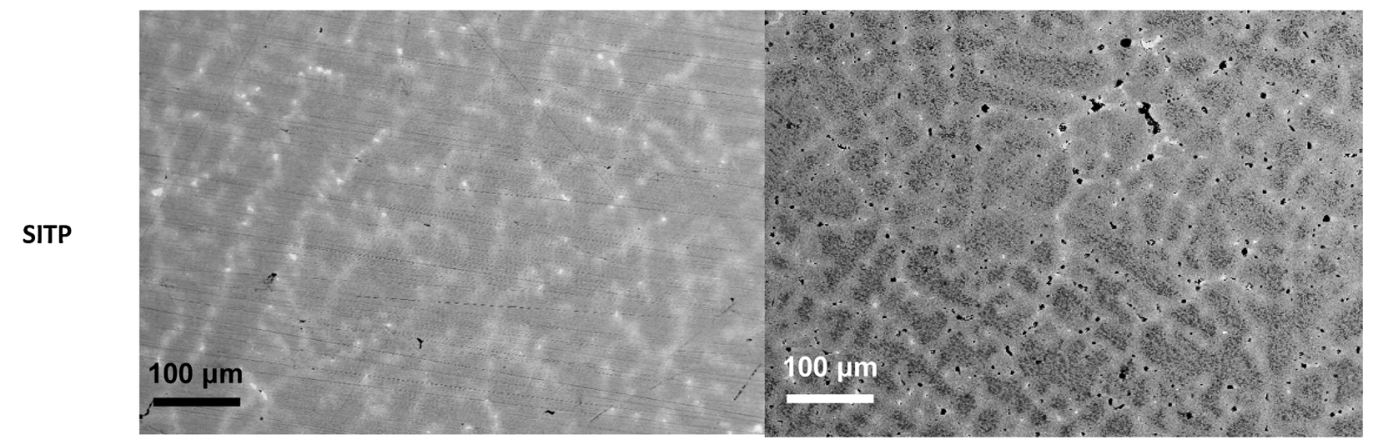

d.

e.

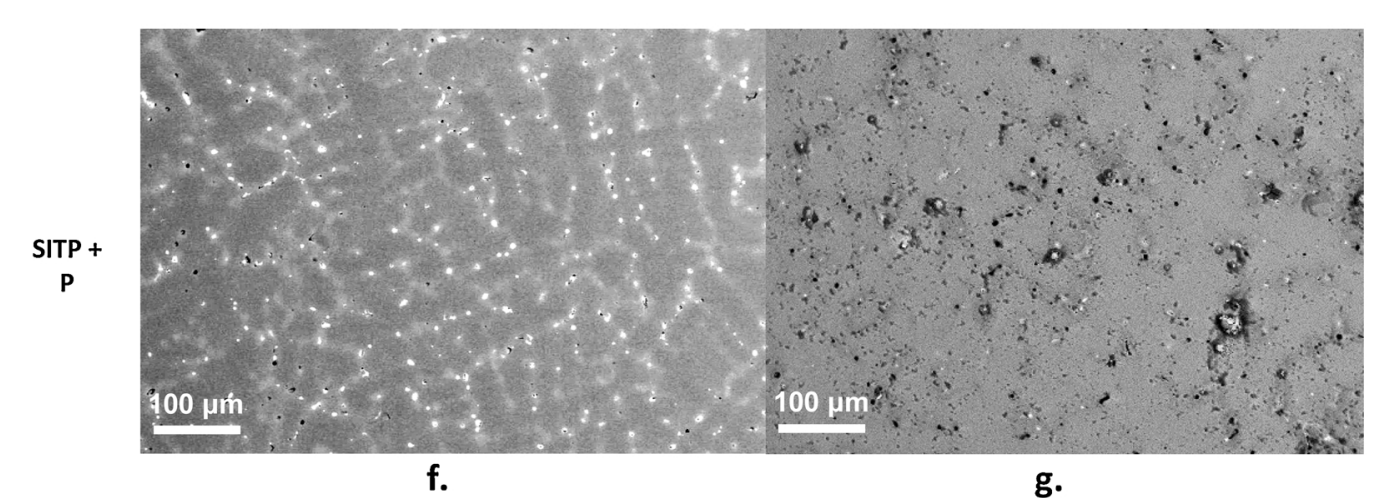

Fig. 11. BSE-SEM micrographs obtained on bare bronze samples (a) and on samples after $1 \mathrm{~h}(\mathrm{~b}, \mathrm{~d}, \mathrm{f})$ or $480 \mathrm{~h}$ (c,e,g) of immersion in ARX10 solution, both in the absence of inhibitors and in the presence of SITP or SITP + P. 


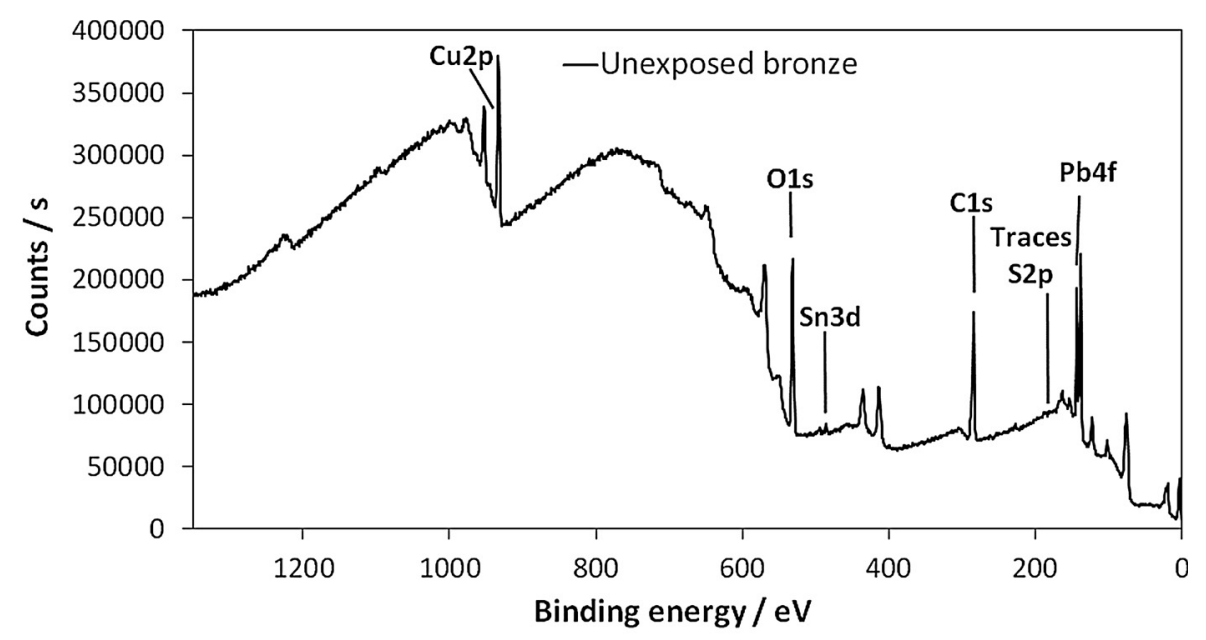

a.

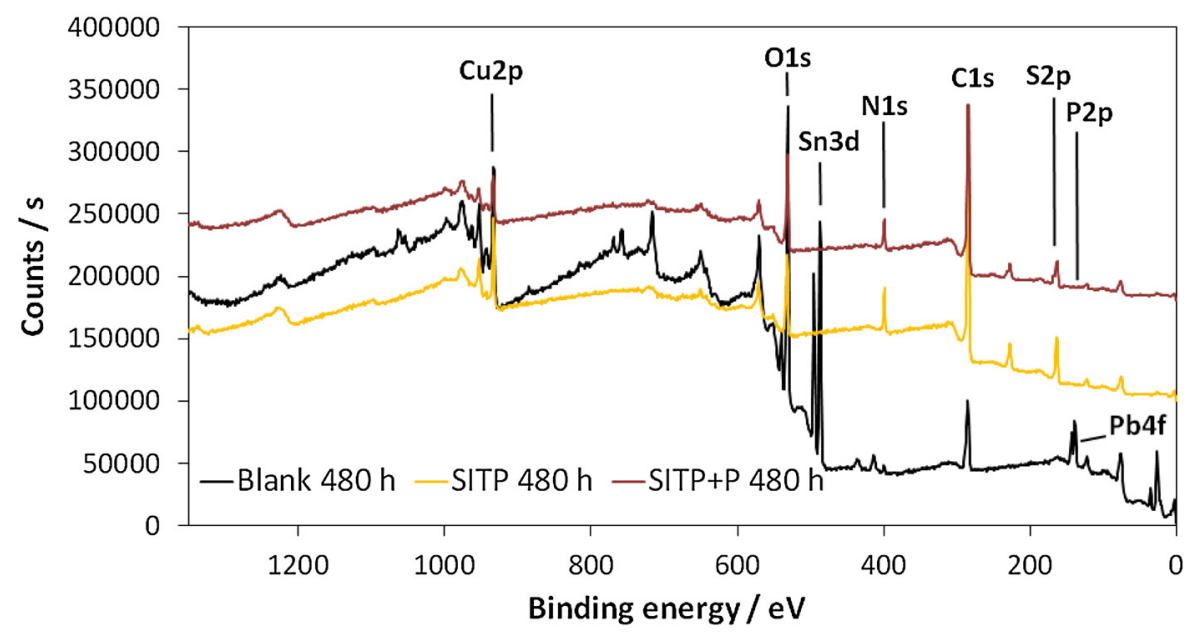

b.

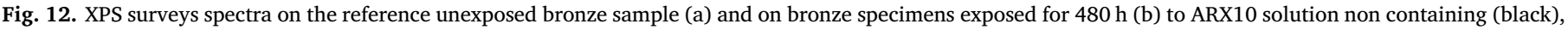
or containing SITP and SITP $+\mathrm{P}$.

polarization curves.

A quite different film was present after long immersion periods in the blank solution (survey spectrum in Fig. 12b). In fact, beside surface $\mathrm{C}$ contamination (core level spectrum in Fig. 13a), this film was characterized by the presence of a small N $1 \mathrm{~s}$ peak at $399.6 \mathrm{eV}$, compatible with the deposition of small amounts of ammonium compounds after reaction with ammonium ions in ARX10 (Fig. 13b), and a high $01 \mathrm{~s}$ peak at $531.0 \mathrm{eV}$ (Fig. 13c), compatible with oxide formation [36]. Cu 2p core level spectrum (Figs. 13e) showed a high peak at $932.3 \mathrm{eV}$ and a smaller one at $934.5 \mathrm{eV}$, with a significant shake-up satellite peak at 940-944 eV, suggesting the concomitant presence of $\mathrm{Cu}(\mathrm{I}) / \mathrm{Cu}(0)$ and $\mathrm{Cu}$ (II) species. The Auger $\mathrm{Cu} \mathrm{L}_{3} \mathrm{M}_{4,5} \mathrm{M}_{4,5}$ signal at $916.8 \mathrm{eV}$ (kinetic energy, $\mathrm{KE}$ ) and the shoulder at lower $\mathrm{KE}$ suggested the presence of $\mathrm{Cu}$ (I) and $\mathrm{Cu}(\mathrm{II})$ compounds [60]. Core level spectra of Sn 3d (Fig. 13g), $\mathrm{Pb} 4 \mathrm{f}$ (Fig. 13h) and Sb 3d (the last one not reported in Fig. 13) showed peaks at $486.7 \mathrm{eV}\left(\mathrm{Sn} 3 \mathrm{~d}_{5 / 2}\right), 138.5 \mathrm{eV}\left(\mathrm{Pb}_{7 / 2}\right)$ and $540.1 \mathrm{eV}\left(\mathrm{Sb}_{7 / 2}\right)$, respectively, indicating the presence of $\mathrm{Sn}$ (IV) [53-57], Sb(III) [61] and $\mathrm{Pb}$ ) $[58,59]$ oxides. As regards $\mathrm{Pb}$, the binding energies of $\mathrm{Pb}$ oxides were too close to each other to allow for a precise attribution, but, on the basis of the $\mathrm{E}_{\text {cor }}$ values of bronze in ARX10, the presence of $\mathrm{Pb}(\mathrm{II})$ (PbO-like) species was more likely [62].

The XPS results reported in Table 2 confirm the surface decuprification of bronze due to corrosion revealed from the SEM-EDS analysis. The $\mathrm{Cu} / \mathrm{Sn}$ atomic ratio decreased from about 29 in the unexposed sample to 1.16 after exposure to the blank solution. Also $\mathrm{Pb}$ underwent a preferential dissolution because of a concurrent significant decrease in $\mathrm{Pb} / \mathrm{Sn}$ ratio.

After $480 \mathrm{~h}$ of immersion in SITP solution (survey in Fig. 12b), XPS spectra revealed the formation of a SITP-containing film, as indicated by the increase in the content of the inhibitor elements. In fact, an increase in the $\mathrm{N} 1 \mathrm{~s}$ peak at $399.2 \mathrm{eV}$, related to organic $\mathrm{N}-\mathrm{C}$ bonds $[18,27,50]$ (Fig. 13b), and a rise in specific C $1 \mathrm{~s}$ and S 2p signals were detected. In particular (Fig. 13a), instead of the C1 s peak at $287.5 \mathrm{eV}$ related to surface contaminants which almost disappeared, high $\mathrm{C} 1 \mathrm{~s}$ peaks at $284.4 \mathrm{eV}$ and $286.0 \mathrm{eV}$ were obtained: the former corresponding to organic $\mathrm{C}-\mathrm{C}$ and $\mathrm{C}-\mathrm{H}$ bonds, and the latter related to $\mathrm{C}-\mathrm{O}$, $\mathrm{C}-\mathrm{S}$ and $\mathrm{C}-\mathrm{N}$ bonds [52]. The intense $\mathrm{S} 2 \mathrm{p}_{3 / 2}$ peak at $163.5 \mathrm{eV}$ was also related to $\mathrm{S}-\mathrm{C}$ and $\mathrm{S}-\mathrm{H}$ bonds of the inhibitor, while the shoulder at $162.3 \mathrm{eV}$ suggested the interesting formation of coordination bonds of $\mathrm{S}$-Cu type [50,52]. The third shift of $S 2 p$ transition was indicative of the deposit of quite limited amounts of sulphates as corrosion products (Fig. 13d) [63]. Analysis of the $\mathrm{Cu} 2 \mathrm{p}$ core level (Fig. 13e) disclosed a small peak (much smaller than in the blank) at $932.7 \mathrm{eV}$ and a shoulder at $934.5 \mathrm{eV}$, with a tiny shake-up satellite peak at $940-944 \mathrm{eV}$. This spectrum, in association with the Auger $\mathrm{Cu} \mathrm{L}_{3} \mathrm{M}_{4,5} \mathrm{M}_{4,5}$ signal at $916.0 \mathrm{eV}$ (KE) (Fig. 13f), was indicative of the predominant presence of $\mathrm{Cu}(\mathrm{I})$ species over $\mathrm{Cu}$ (II) species (Table 2) [60], meaning, therefore, that the surface film was essentially composed of $\mathrm{Cu}(\mathrm{I})$-SITP complexes based on $\mathrm{Cu}(\mathrm{I})-\mathrm{S}$ bond formation. The intense $\mathrm{S} 2 \mathrm{p}_{3 / 2}$ at $163.5 \mathrm{eV}$, correlated to $\mathrm{S}-\mathrm{H}$ and/or $\mathrm{S}-\mathrm{C}$, was even more pronounced than that 


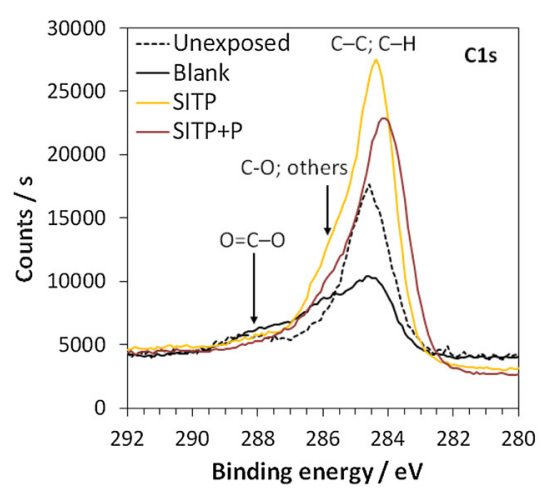

a.

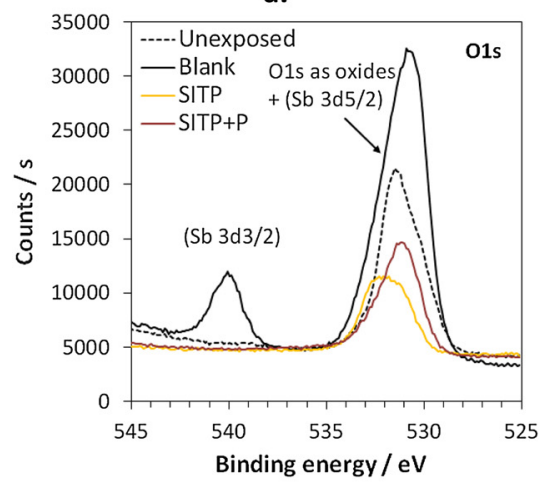

c.

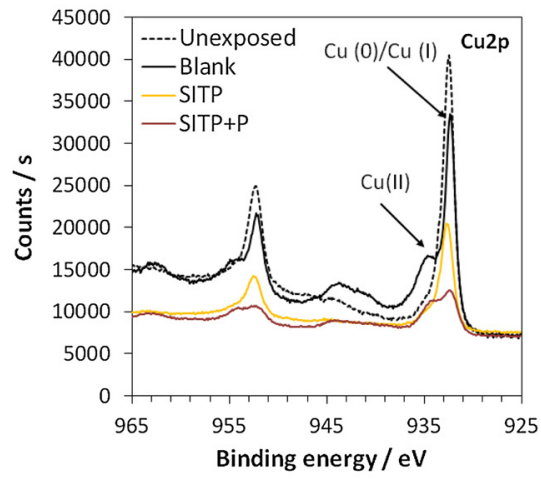

e.

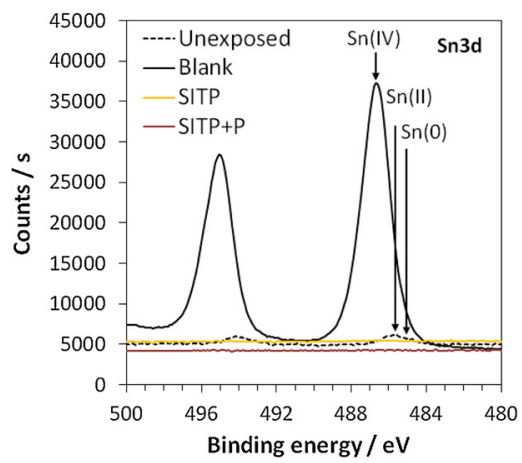

g.

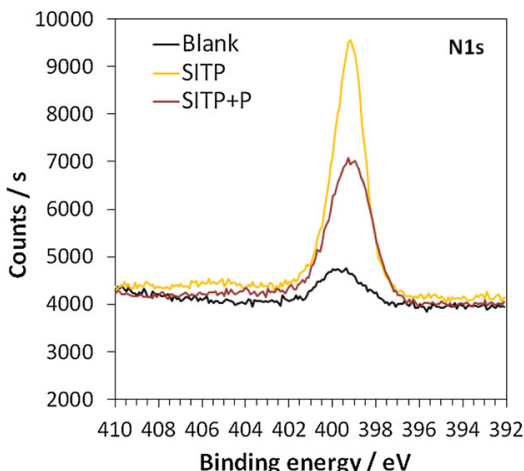

b.

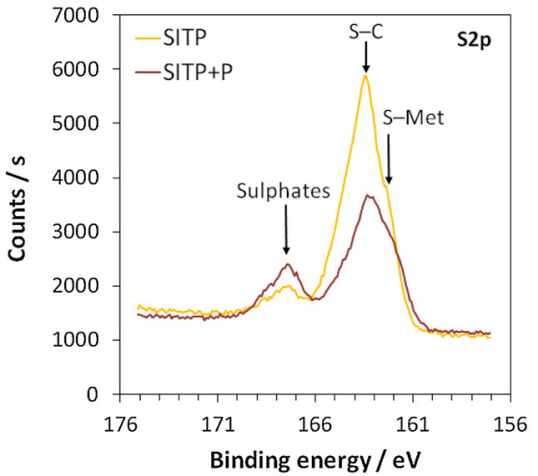

d.

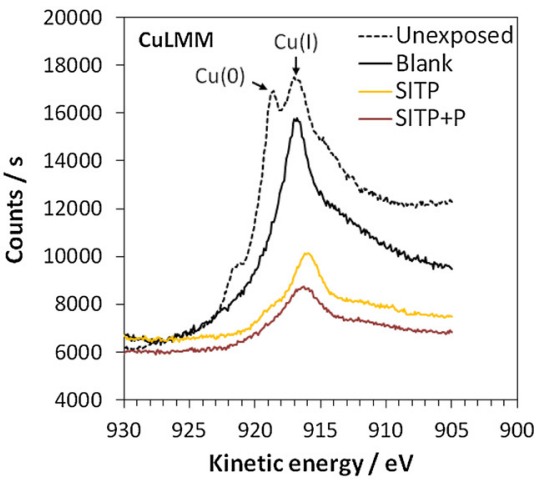

f.

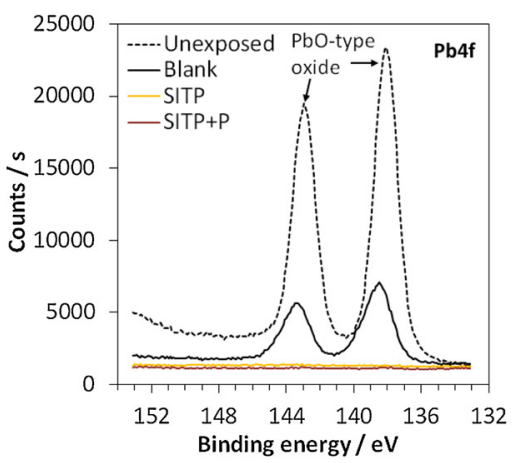

h.

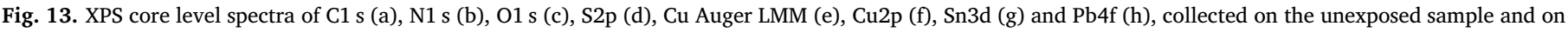
samples exposed for $480 \mathrm{~h}$ to uninhibited (Blank) or inhibited (SITP o SITP + P) ARX10 solution.

related to the S-Cu(I) structure, suggesting the concomitant presence of adsorbed SITP molecules in the film not involved in complex formation. This would also justify the high $\mathrm{N} / \mathrm{Cu}(\mathrm{I})$ ratio (much higher than 1 ) again correlated to the presence of adsorbed SITP molecules, in addition to $\mathrm{Cu}(\mathrm{I})$-SITP complexes. The XPS analysis also detected small amounts of sulphates, most likely $\mathrm{Cu}(\mathrm{II})$ salts.

In the presence of SITP $+\mathrm{P}$, quite similar results were achieved, confirming the formation of a SITP film of adsorbed molecules and $\mathrm{Cu}$ 
Table 2

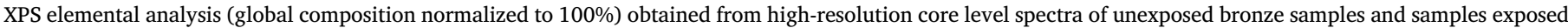
for $480 \mathrm{~h}$ to ARX10 solution both in the absence of inhibitors and in the presence of SITP or SITP + P

\begin{tabular}{|c|c|c|c|c|c|c|c|c|c|c|c|c|c|c|c|c|}
\hline \multirow[t]{2}{*}{ Specimen } & \multicolumn{3}{|l|}{$\mathrm{C} 1 \mathrm{~s}$} & \multirow{2}{*}{$\begin{array}{l}\mathrm{N} 1 \mathrm{~s} \\
\mathrm{NC}, \mathrm{NH}\end{array}$} & \multirow{2}{*}{$\begin{array}{l}\text { O } 1 \mathrm{~s} \\
\#\end{array}$} & \multirow[t]{2}{*}{ P 2p } & \multicolumn{3}{|l|}{$\mathrm{S} 2 \mathrm{p}_{3 / 2}$} & \multicolumn{2}{|l|}{$\mathrm{Cu} 2 \mathrm{p}_{3 / 2}$} & \multicolumn{3}{|c|}{ Sn $3 d_{5 / 2}$} & \multirow{2}{*}{$\begin{array}{l}\mathrm{Sb} 3 \mathrm{~d}_{3 / 2} \\
\text { oxide } \\
\text { (s) }\end{array}$} & \multirow{2}{*}{$\begin{array}{l}\mathrm{Pb} 4 \mathrm{f}_{7 / 2} \\
\text { PbO-like } \\
\text { (s) }\end{array}$} \\
\hline & $\mathrm{CC}, \mathrm{CH}$ & $\begin{array}{l}\text { C-O*, } \\
\text { C-S, } \\
\text { C-N }\end{array}$ & $\begin{array}{l}\mathrm{C}=\mathrm{O} \\
\mathrm{O}-\mathrm{C}=\mathrm{O}\end{array}$ & & & & S-Metal & $\begin{array}{l}\text { SH, S-C, } \\
\ldots\end{array}$ & $\begin{array}{l}\text { Sulfate } \\
\ldots\end{array}$ & $\begin{array}{l}\left(\mathrm{Cu}^{\circ}\right) \mathrm{Cu} \\
\text { (I) }\end{array}$ & $\mathrm{Cu}(\mathrm{II})$ & $\mathrm{Sn}^{\circ}$ & $\begin{array}{l}\mathrm{Sn}(\mathrm{II}) \\
(\mathrm{SnO})\end{array}$ & $\begin{array}{l}\mathrm{Sn} \\
\text { (IV) }\left(\mathrm{SnO}_{2}\right)\end{array}$ & & \\
\hline
\end{tabular}

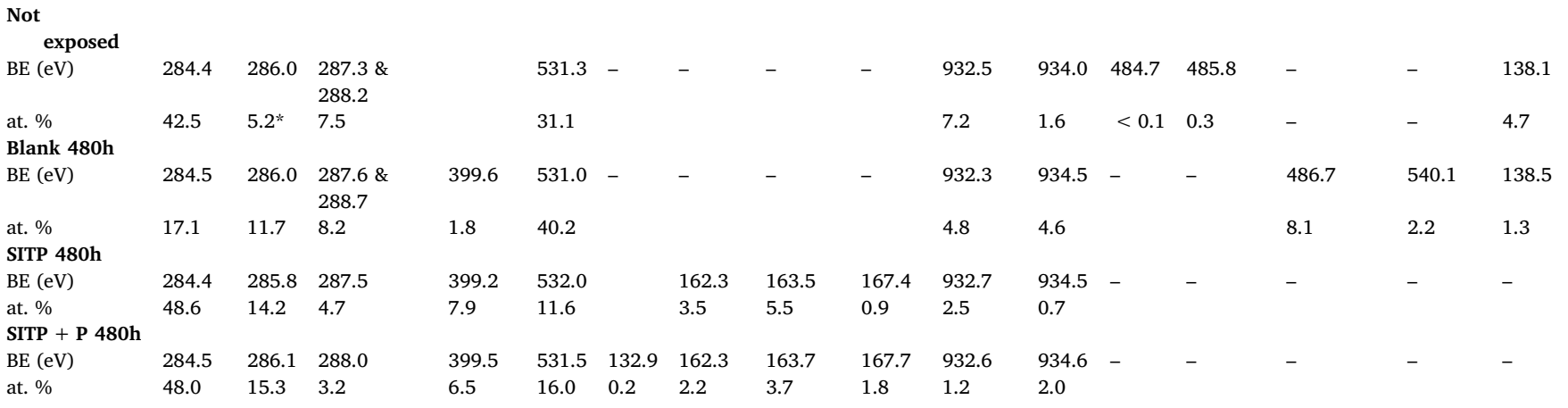

\# very broad peak including oxide, hydroxide, C-O and sulfate bindings.

(I)-complexes. However, in this case the atomic percentages of $\mathrm{N}$ atoms and $\mathrm{S}$ atoms related to the inhibitor (i.e. both S-Metal and S-H/S-C bonds) and particularly the $\mathrm{Cu}(\mathrm{I})$ species (likely involved in the complex formation) were lower than in the sample exposed to SITP. This would suggest that both the overall SITP amount and particularly the relative quantity of $\mathrm{Cu}(\mathrm{I})$-SITP complexes per adsorbed molecules were smaller than in the case of the SITP alone. Thus, a thinner SITP film is to be expected with a smaller $\mathrm{Cu}$ complex fraction. Again, in comparison to SITP sample, the SITP + P sample also showed slightly higher amounts of $\mathrm{Cu}(\mathrm{II})$ ions and $\mathrm{S}$ atoms involved in sulphate species. Finally, a limited but significant atomic percentage of phosphorus atoms ascribed to phosphates [64] in the film was detected, most likely connected to the surface precipitation of $\mathrm{Cu}$ (II) phosphates at film defects where the concentration of dissolved $\mathrm{Cu}(\mathrm{II})$ ion was higher. This mechanism of defect healing may have been present in the film since the beginning of the immersion.

In agreement with SEM observation, no $\mathrm{Pb}$ signal was detected, in either SITP or SITP + P solutions, due to its significant dissolution after long immersion times, as previously evidenced by SEM observation (Fig. 11).

\section{Discussion}

The investigated Schiff bases afford quite different inhibiting efficiency $(\eta)$ values, as a result of their different concentrations and molecular structures. In spite of their limited solubility determining low saturation concentrations, high $\eta$ values of $77.3,94.6$ and $99.91 \%$ are obtained by addition of MSITP, TPIE and SITP, respectively, in good agreement with $\eta_{R p}$ values, meaning that small amounts of these substances are sufficient to protect bronze. These substances contain a mercapto group in the molecule, which ensures a stronger chemisorption on bronze, due to its high chemical affinity with $\mathrm{Cu}$ cations on bronze surface. In the case of SITP, exhibiting the highest solubility, the best inhibition performances were accordingly achieved. Polarization curves recorded after $480 \mathrm{~h}$ immersion in ARX10 show that these three substances act as mixed corrosion inhibitors and increase the potential of surface film breakdown by chlorides on bronze.

By addition of $P$ to SITP solution, excellent $\eta$ quite close to that in SITP solution and a remarkable increase in breakage potential is achieved. Therefore, the inhibition mechanisms of both SITP and SITP $+\mathrm{P}$ additives were investigated by a combination of electrochemical and surface analysis techniques.
Surface analyses show that these substances induce a strong modification of the surface film, which in the blank solution is largely composed of $\mathrm{Cu}_{2} \mathrm{O}$, hydrated $\mathrm{SnO}_{\mathrm{x}}$, PbO-like oxide. According to XPS results, the surface film formed in SITP solution contains both $\mathrm{Cu}(\mathrm{I})$ SITP complexes, based on $\mathrm{Cu}(\mathrm{I})-\mathrm{S}$ bond formation, and adsorbed SITP molecules. Quite similar results have been obtained by other authors [65] with different S-containing organic inhibitors of copper corrosion, which were reported to produce duplex organic films, including a first chemisorbed layer, on top of which a physisorbed multilayer grows. The stability of the multilayer arises because of $\pi$-stack interactions between aromatic rings and Van der Waals bonds between polarizable substitutional functional groups [19,66]. EIS analysis clearly highlights that in SITP solution the film builds up with time and is quite stable, with negligible $\mathrm{Cu}(\mathrm{I}) \leftrightarrows \mathrm{Cu}$ reactivity. Despite the slow growth, it is able to hinder charge transfer and offers high protectiveness already at short immersion times.

The addition of $\mathrm{P}$ to SITP solution determines the formation of a thinner surface film (as suggested by XPS results and by the relatively small $R_{f}$ values obtained by EIS), again composed of a first Cu(I)-SITP complex layer, covered by adsorbed SITP molecules. In comparison to the film in SITP solution, the presence of a smaller fraction of $\mathrm{Cu}(\mathrm{I})$ SITP complex could negatively affect the adhesion of the film on bronze, thus justifying its higher faradaic activity. However, the precipitation of $\mathrm{Cu}(\mathrm{II})$ phosphate at flaws of the inhibitor film helps to limit the solution access to the metal surface, so maintaining high $R_{t}$ and finally high overall $\mathrm{R}_{\mathrm{p}}$ values. Pore plugging by $\mathrm{Cu}(\mathrm{II})$ phosphate precipitation is stimulated during anodic polarization, leading to strong passive conditions.

\section{Conclusions}

1 Among the new Schiff bases specifically synthesized and tested as bronze corrosion inhibitors in tenfold concentrated synthetic acid rain (ARX10), those containing a mercapto group exhibit good inhibiting efficiencies during $480 \mathrm{~h}$ immersions. In particular, SITP characterized by the highest solubility (about $0.7 \mathrm{mM}$, in comparison to $0.4 \mathrm{mM}$ of TPIE and $0.3 \mathrm{mM}$ of MSITP) shows an inhibiting efficiency value of almost $100 \%$.

2 SITP protects bronze by forming a surface film containing both $\mathrm{Cu}$ (I)-SITP complexes and SITP molecules, the latter most likely physisorbed on the first $\mathrm{Cu}(\mathrm{I})$-SITP layer.

3 In the presence of SITP and sodium dihydrogen phosphate (P), 
bronze results more resistant against localized attack.

4 In SITP + P solution, a SITP thinner film forms on bronze. P determines the precipitation of $\mathrm{Cu}(\mathrm{II})$ phosphates at flaws of the surface film, particularly under anodic polarization.

5 SITP and SITP + P addition significantly hinders bronze decuprification.

\section{Acknowledgments}

This research was carried out in the scope of the B-IMPACT project (project ID 1149) within the M-ERA.NET 2013 network, supported by the national funding organisations: Ministrstvo za izobraževanje, znanost in šport (MIZS) Slovenia, Ministero dell'Istruzione, dell'Università e della Ricerca (MIUR) Italy and Region Midi-Pyrénéés (RMP) France.

\section{References}

[1] C. Monticelli, V. Grassi, G. Mavilia, F. Zanotto, A. Balbo, Entrapment of corrosion inhibitors in silane coatings to improve bronze corrosion protection, Proc. of EUROCORR 2017 \& 20th ICC \& Process Safety Congress 2017, 3-7 Sept, Prague, 2017 Paper n. 82386.

[2] S. Golfomitsou, J.F. Merkel, Synergistic effects of corrosion inhibitors for copper and copper alloy archaeological artefacts, Proceedings of Metal 2004, National Museum of Australia Canberra ACT, 4-8 October, 2004, pp. 344-368.

[3] K. Rahmouni, N. Hajaji, M. Keddam, A. Srhiri, H. Takenouti, The inhibiting effect of 3-methyl 1,2,4-triazole 5-thione on corrosion of copper in $3 \% \mathrm{NaCl}$ in presence of sulphide, Electrochim. Acta 52 (2007) 7519, https://doi.org/10.1016/j.electacta. 2006.12.079.

[4] C. Degrigny, V. Argyropoulos, P. Pouli, M. Grech, K. Kreislova, M. Harith, F. Mirambet, N. Haddad, E. Angelini, E. Cano, N. Hajjaji, A. Ciringiroglu, A. Almansour, L. Mahfoud, The methodology of the PROMET project to develop/ test new non-toxic corrosion inhibitors and coatings for iron and copper alloy objects housed in Mediterranean museums, Proceedings of Metal 2007, Rijksmuseum, Amsterdam, 2007, p. 31.

[5] A. Balbo, C. Chiavari, C. Martini, C. Monticelli, Effectiveness of corrosion inhibitor films for the conservation of bronzes and gilded bronzes, Corros. Sci. 59 (2012) 204, https://doi.org/10.1016/j.corsci.2012.03.003.

[6] K. Marušić, H. Otmačić Curković, H. Takenouti, Inhibiting effect of 4-methyl-1-ptolylimidazole to the corrosion of bronze patinated in sulphate medium, Electrochim. Acta 56 (2011) 7491, https://doi.org/10.1016/j.electacta.2011.06. 107.

[7] L. Ying, F. Haitao, Z. Yifan, W. Wuji, Study on the inhibiting behavior of AMT on bronze in 5\% citric acid solution, J. Mater. Sci. 38 (2003) 407-411, https://doi.org/ 10.1023/A:1021803211415.

[8] D.C.B. Do Lago, L.F. De Senna, E.C.S. Soares, L.F. Da Silva, D.S. Fernandes, A.S. Luna, E. D'elia, The use of experimental design for the study of the corrosion of bronze pretreated with AMT in artificial rainwater, Progr. Org. Coat. 76 (2013) 1289, https://doi.org/10.1016/j.porgcoat.2013.03.032.

[9] M.M. Antonijević, S.M. Milić, M.B. Petrović, Films formed on copper surface in chloride media in the presence of azoles, Corros. Sci. 51 (2009) 1228-1237, https:// doi.org/10.1016/j.corsci.2009.03.026

[10] J.B. Cotton, I.R. Scholes, Benzotriazole and related compounds as corrosion inhibitors for copper, Br. Corros. J. 2 (1967) 1-5, https://doi.org/10.1179/ 000705967798327235.

[11] F. Zucchi, G. Trabanelli, M. Fonsati, Tetrazole derivatives as corrosion inhibitors for copper in chloride solutions, Corros. Sci. 38 (1996) 2019-2029, https://doi.org/10. 1016/S0010-938X(96)00094-7.

[12] R. Subramanian, V. Lakshminarayanan, Effect of the adsorption of some azoles on copper passivation in alkaline medium, Corros. Sci. 44 (2002) 535-554, https://doi. org/10.1016/S0010-938X(01)00085-3.

[13] N. Kovačević, A. Kokalj, The relation between adsorption bonding and corrosion inhibition of azole molecules on copper, Corros. Sci. 73 (2013) 7-17, https://doi org/10.1016/j.corsci.2013.03.016.

[14] N. Kovačević, I. Milošev, A. Kokalj, How relevant is the adsorption bonding of imidazoles and triazoles for their corrosion inhibition of copper? Corros. Sci. 124 (2017) 25-34, https://doi.org/10.1016/j.corsci.2017.04.021.

[15] M.B. Petrović Mihajlović, M.B. Radovanović, ž.Z. Tasić, M.M. Antonijević, Imidazole based compounds as copper corrosion inhibitors in seawater, J. Mol. Liq. 225 (2017) 127-136, https://doi.org/10.1016/j.molliq.2016.11.038.

[16] B.-S. Fang, C.G. Olson, D.W. Lynch, A photoemission study of benzotriazole on clean copper and cuprous oxide, Surf. Sci. 176 (1986) 476-490, https://doi.org/10. 1016/0039-6028(86)90050-6.

[17] D. Tromans, R.-H. Sun, Anodic Polarization Behavior of Copper in Aqueous Chloride/Benzotriazole Solutions, J. Electrochem. Soc. 138 (1991) 3235-3244, https://doi.org/10.1149/1.2085397.

[18] L. Tommesani, G. Brunoro, A. Frignani, C. Monticelli, M. Dal Colle, On the protective action of 1,2,3-benzotriazole derivative films against copper corrosion, Corros. Sci. 39 (1997) 1221-1237, https://doi.org/10.1016/S0010-938X(97) 00022-X.

[19] M.M. Antonijević, M.B. Petrović, Copper corrosion inhibitors. A review, Int. J.
Electrochem. Sci. 3 (2008) 1-28 http://www.electrochemsci.org/papers/vol3/ 3010001.pdf.

[20] M. Finšgar, I. Milošev, Inhibition of copper corrosion by 1,2,3-benzotriazole: A review, Corros. Sci. 52 (2010) 2737-2749, https://doi.org/10.1016/j.corsci.2010. 05.002 .

[21] G. Xue, J. Ding, P. Lu, J. Dong, SERS, XPS and electroanalytical studies of the chemisorption of benzotriazole on a freshly etched surface and an oxidized surface of copper, J. Phys. Chem. 95 (1991) 7380-7384, https://doi.org/10.1021/ j100172a050.

[22] Z. Chen, L. Huang, G. Zhang, Y. Qiu, X. Guo, Benzotriazole as a volatile corrosion inhibitor during the early stage of copper corrosion under adsorbed thin electrolyte layers, Corros. Sci. 65 (2012) 214-222, https://doi.org/10.1016/j.corsci.2012.08. 019.

[23] H. Bi, G.T. Burstein, B.B. Rodriguez, G. Kawaley, Some aspects of the role of inhibitors in the corrosion of copper in tap water as observed by cyclic voltammetry, Corros. Sci. 102 (2016) 510-516, https://doi.org/10.1016/j.corsci.2015.11.005.

[24] A.D. Modestov, G.-D. Zhoua, Y.-P. Wua, T. Notoya, D.P. Schweinsberg, A study of the electrochemical formation of Cu(I)-BTA films on copper electrodes and the mechanism of copper corrosion inhibition in aqueous chloride/benzotriazole solutions, Corros. Sci. 36 (1994) 1931-1946, https://doi.org/10.1016/j.corsci.2015.11. 005.

[25] M. Finšgar, S. Peljhan, A. Kokalj, J. Kovač, I. Milošev, Determination of the $\mathrm{Cu}_{2} \mathrm{O}$ thickness on BTAH-inhibited copper by reconstruction of Auger electron spectra, J. Electrochem. Soc. 157 (2010) C295-C301, https://doi.org/10.1149/1.3463718.

[26] M. Finšgar, D. Kek Merl, 2-Mercaptobenzoxazole as a copper corrosion inhibitor in chloride solution: electrochemistry, 3D-profilometry, and XPS surface analysis, Corros. Sci. 80 (2014) 82-95, https://doi.org/10.1016/j.corsci.2013.11.022.

[27] T. Kosec, D. Kek Merl, I. Milošev, Impedance and XPS study of benzotriazole films formed on copper, copper-zinc alloys and zinc in chloride solution, Corros. Sci. 50 (2008) 1987-1997, https://doi.org/10.1016/j.corsci.2008.04.016.

[28] D.A. Pillard, J.S. Cornell, D.L. Dufresne, M.T. Hernández, Toxicity of benzotriazole and benzotriazole derivatives to three aquatic species, Water Res. 35 (2001) 557, https://doi.org/10.1016/S0043-1354(00)00268-2.

[29] Health Council of the Netherlands, 1,2,3-Benzotriazole. Health-based Recommended Occupational Exposure Limit. The Hague: Health Council of the Netherlands, (2000) publication no.2000/14OSH. ISBN 90-5549-348-1.

[30] H. Ma, S. Chen, L. Niu, S. Zhao, S. Li, D. Li, Inhibition of copper corrosion by several Schiff; bases in aerated halide solutions, J. Appl. Electrochem. 32 (2002) 65-72, https://doi.org/10.1023/A:1014242112512.

[31] C. Monticelli, G. Brunoro, A. Frignani, A. Marchi, The inhibitive action of some Schiff Bases and amines towards the corrosion of copper in an aqueous alcoholic medium, Surf. Technol. 27 (1986) 175, https://doi.org/10.1016/0257-8972(86) 90128-3.

[32] Z. Quan, S. Chen, Y. Li, X. Cui, Adsorption behaviour of Schiff base and corrosion protection of resulting films to copper substrate, Corros. Sci. 44 (2002) 703-715, https://doi.org/10.1016/S0010-938X(01)00077-4.

[33] M. Ehteshamzade, T. Shahrabi, M.G. Hosseini, Inhibition of copper corrosion by self-assembled films of new Schiff bases and their modification with alkanethiols in aqueous medium, Appl. Surf. Sci. 252 (2006) 2949, https://doi.org/10.1016/j apsusc.2005.05.003.

[34] N. Ochoa, F. Moran, N. Pébère, The synergistic effect between phosphonocarboxylic acid salts and fatty amines for the corrosion protection of a carbon steel, J. Appl. Electrochem. 34 (2004) 487, https://doi.org/10.1023/B:JACH.0000021702. 49827.11.

[35] C. Chiavari, A. Balbo, E. Bernardi, C. Martini, M.C. Bignozzi, M. Abbottoni, C. Monticelli, Protective silane treatment for patinated bronze exposed to simulated natural environments, Mater. Chem. Phys. 141 (2013) 502-511, https://doi.org/ 10.1016/j.matchemphys.2013.05.050.

[36] G. Masi, A. Balbo, J. Esvan, C. Monticelli, J. Avila, L. Robbiola, E. Bernardi, M.C. Bignozzi, M.C. Asensio, C. Martini, C. Chiavari, X-ray Photoelectron Spectroscopy as a tool to investigate silane-based coatings for the protection of outdoor bronze: The role of alloying elements, Appl. Surf. Sci. 433 (2018) 468-479, https://doi.org/10.1016/j.apsusc.2017.10.089.

[37] C. Chiavari, E. Bernardi, A. Balbo, C. Monticelli, S. Raffo, M.C. Bignozzi, C. Martini, Atmospheric corrosion of fire-gilded bronze: corrosion and corrosion protection during accelerated ageing tests, Corros. Sci. 100 (2015) 435-447, https://doi.org/ 10.1016/j.corsci.2015.08.013.

[38] F. Cao, Z. Shi, J. Hofstetter, P.J. Uggowitzer, G. Song, M. Liu, A. Atrens, Corrosion of ultra-high-purity $\mathrm{Mg}$ in 3.5\% $\mathrm{NaCl}$ solution saturated with $\mathrm{Mg}(\mathrm{OH})_{2}$, Corros. Sci. 75 (2013) 78-99, https://doi.org/10.1016/j.corsci.2013.05.018.

[39] K. Marušić, H. Otmačić Ćurković, Š. Horvat-Kurbegović, H. Takenouti, E. StupnišekLisac, Comparative studies of chemical and electrochemical preparation of artificial bronze patinas and their protection by corrosion inhibitor, Electrochim. Acta 54 (2009) 7106-7113, https://doi.org/10.1016/j.electacta.2009.07.014.

[40] R. Bostan, S. Varvara, L. Găină, L.M. Muresan, Evaluation of some phenothiazine derivatives as corrosion inhibitors for bronze in weakly acidic solution, Corros. Sci. 63 (2012) 275-286, https://doi.org/10.1016/j.corsci.2012.06.010.

[41] J.R. Macdonald, Impedance Spectroscopy, Wiley, New York, 1987, p. 1.

[42] J.B. Jorcin, M.E. Orazem, N. Pébère, B. Tribollet, CPE analysis by local electrochemical impedance spectroscopy, Electrochim. Acta 51 (2006) 1473-1479, https://doi.org/10.1016/j.electacta.2005.02.128.

[43] C.H. Hsu, F. Mansfeld, Concerning the conversion of the constant phase element parameter Y0 into a capacitance, Corrosion 57 (2001) 747-748, https://doi.org/10. 5006/1.3280607.

[44] G.J. Brug, A.L.G. van den Eeden, M. Sluyters-Rehbach, J.H. Sluyters, The analysis of electrode impedances complicated by the presence of a constant phase element, J. 
Electroanal. Chem. 176 (1984) 275, https://doi.org/10.1016/S0022-0728(84) 80324-.

[45] A. Dermaj, N. Hajjaji, S. Joiret, K. Rahmouni, A. Srhiri, H. Takenouti, V. Vivier, Electrochemical and spectroscopic evidences of corrosion inhibition of bronze by a triazole derivative, Electrochim. Acta 52 (2007) 4654-4662, https://doi.org/10. 1016/j.electacta.2007.01.068.

[46] S. Varvara, L. Muresan, K. Rahmouni, H. Takenouti, Evaluation of some non-toxic thiadiazole derivatives as bronze corrosion inhibitors in aqueous solution, Corros. Sci. 50 (2008) 2596-2604, https://doi.org/10.1016/j.corsci.2008.06.046.

[47] X.T. Wang, J. Wang, Y. Wu, The inhibition effect and mechanism of L -cysteine on the corrosion of bronze covered with a CuCl patina, Corros. Sci. 97 (2015) 89-99, https://doi.org/10.1016/j.corsci.2015.04.018.

[48] K. Rahmouni, H. Takenouti, N. Hajjaji, A. Srhiri, L. Robbiola, Protection of ancient and historic bronzes by triazole derivatives, Electrochim. Acta 54 (2009) 5206-5215, https://doi.org/10.1016/j.electacta.2009.02.027.

[49] S. Varvara, R. Bostan, O. Bobis, L. Găină, F. Popa, V. Mena, R.M. Souto, Propolis as a green corrosion inhibitor for bronze in weakly acidic solution, Appl. Surf. Sci. 426 (2017) 1100-1112, https://doi.org/10.1016/j.apsusc.2017.07.230.

[50] W. Qafsaoui, A. Et Taouil, M.W. Kendig, H. Cachet, S. Joiret, H. Perrot, H. Takenouti, Coupling of electrochemical, electrogravimetric and surface analysis techniques to study dithiocarbamate/bronze interactions in chloride media, Corros. Sci. 130 (2018) 190-202, https://doi.org/10.1016/j.corsci.2017.10.034.

[51] A. Mezzi, E. Angelini, T. De Caro, S. Grassini, F. Faraldi, C. Riccucci, G.M. Ingo, Investigation of the benzotriazole inhibition mechanism of bronze disease, Surf. Interface Anal. 44 (2012) 968-971, https://doi.org/10.1002/sia.4841.

[52] F. Sinapi, S. Julien, D. Auguste, L. Hevesi, J. Delhalle, Z. Mekhalif, Monolayers and mixed-layers on copper towards corrosion protection, Electrochim. Acta 53 (2008) 4228-4238, https://doi.org/10.1016/j.electacta.2007.12.061.

[53] L. Kövér, Z. Kovács, R. Sanjinés, G. Moretti, I. Cserny, G. Margaritondo, J. Pálinkás, $\mathrm{H}$. Adachi, Electronic structure of tin oxides: high-resolution study of XPS and Auger spectra, Surf. Interfa. 23 (1995) 461-466, https://doi.org/10.1002/sia. 740230705.

[54] L. Robbiola, T.T.M. Tran, P. Dubot, O. Majerus, K. Rahmouni, Characterisation of anodic layers on $\mathrm{Cu}-10 \mathrm{Sn}$ bronze (RDE) in aerated $\mathrm{NaCl}$ solution, Corros. Sci. 50 (2008) 2205-2215, https://doi.org/10.1016/j.corsci.2008.06.003.

[55] P. Sinsermsuksakul, L. Sun, S.W. Lee, H.H. Park, S.B. Kim, C. Yang, R.G. Gordon, Overcoming efficiency limitations of SnS-based solar cells, Adv. Energy Mater. Adv. Energy Mater. (2014) 1400496, https://doi.org/10.1002/aenm.201400496.

[56] J.A. Rodriguez, T. Jirsak, S. Chaturvedi, J. Hrbek, Surface chemistry of $\mathrm{SO}_{2}$ on $\mathrm{Sn}$ and $\mathrm{Sn} / \mathrm{Pt}(111)$ alloys: effects of metal-metal bonding on reactivity toward sulfur, J. Am. Chem. Soc. 120 (1998) 11149-11157, https://doi.org/10.1021/ja982174a.

[57] M. Hutchison, P. Zhou, K. Ogle, J. Scully, Enhanced electrochemical Cu release from commercial Cu-Sn alloys: fate of the alloying elements in artificial perspiration, Electrochim. Acta (2017), https://doi.org/10.1016/j.electacta.2017.04.092.

[58] M. Chan, A. Capek, D.A. Brill, S.J. Garrett, Characterization of the patina formed on a low tin bronze exposed to aqueous hydrogen sulfide, Surf. Interface Anal. 46 (2014) 433-441, https://doi.org/10.1002/sia.5520.

[59] G. Masi, C. Chiavari, J. Avila, J. Esvan, S. Raffo, M.C. Bignozzi, M.C. Asensio, L. Robbiola, C. Martini, Corrosion investigation of fire-gilded bronze involving high surface resolution spectroscopic imaging, Appl. Surf. Sci. 366 (2016) 317-327, https://doi.org/10.1016/j.apsusc.2016.01.101.

[60] M. Finšgar, EQCM and XPS analysis of 1,2,4-triazole and 3-amino-1,2,4-triazole as copper corrosion inhibitors in chloride solution, Corros. Sci. 77 (2013) 350-359, https://doi.org/10.1016/j.corsci.2013.08.026.

[61] L. Yang, J. Huang, L. Cao, L. Shi, Q. Yu, X. Kong, Y. Jie, pH-regulated template-free assembly of $\mathrm{Sb}_{4} \mathrm{O}_{5} \mathrm{Cl}_{2}$ hollow microsphere crystallites with self-narrowed bandgap and optimized photocatalytic performance, Sci. Rep. 6 (2016) 27765, https://doi. org/10.1038/srep27765.

[62] E. Paparazzo, L. Moretto, Surface and interface microchemistry of archaeologica objects studied with X-ray Photoemission Spectroscopy and scanning Auger microscopy, J. Electron. Spectrosc. Relat. Phenom. 76 (1995) 653-658, https://doi org/10.1016/0368-2048(95)02429-8.

[63] M. Finšgar, 2-mercaptobenzimidazole as a copper corrosion inhibitor: part II. Surface analysis using X-ray photoelectron spectroscopy, Corros. Sci. 72 (2013) 90-98, https://doi.org/10.1016/j.corsci.2013.03.010.

[64] S. Li, S. Shi, G. Huang, Y. Xiong, S. Liu, Synergetic tuning charge dynamics and potentials of $\mathrm{Ag}_{3} \mathrm{PO}_{4}$ photocatalysts with boosting activity and stability by facile in situ fluorination, Appl. Surf. Sci. 455 (2018) 1137-1149, https://doi.org/10.1016/ j.apsusc.2018.06.027.

[65] V. Di Castro, F. Allegretti, C. Baldacchini, M.G. Betti, G. Contini, V. Corradini, F. Lamastra, C. Mariani, Growth of 2-mercaptobenzoxazole on $\mathrm{Cu}(100)$ surface: chemisorbed and physisorbed phases, Surf. Sci. 507-510 (2002) 7-11, https://doi. org /10.1016/S0039-6028(02)01166-4.

[66] B.V. Appa Rao, M.N. Reddy, Formation, characterization and corrosion protection efficiency of self-assembled 1-octadecyl-1H-imidazole films on copper for corrosion protection, Arab. J. Chem. 10 (2017) S3270-S3283, https://doi.org/10.1016/j. arabjc.2013.12.026. 